doi:10.7592/FEJF2011.47.plaat

\title{
ORTHODOXY AND ORTHODOX SACRAL BUILDINGS IN ESTONIA FROM THE 11TH TO THE 19TH CENTURIES
}

\author{
Jaanus Plaat
}

\begin{abstract}
The article provides an overview of the history of Orthodoxy, reaching the territories of Estonia and Setomaa (Petseri/Pechersky District) from Russia, as of the 11th century up until the 1840 s, when the Estonian Lutherans began to massively convert to the Russian Orthodox Church. Prior to this changing-of-church-movement, Orthodox and Old Believers' congregations in Estonia primarily comprised the Russians living or temporarily residing in Estonia, and in Setomaa - the Seto people and Russians. In addition, the so-called poluverniks of Virumaa area are also dealt with. The article focuses on the establishment of Orthodox churches, convents, monasteries and chapels (incl. Seto tsässons) in the territory of the present-day Republic of Estonia and the Petseri/Pechersky District in the Pskov Oblast, Russia (the habitat of Seto people). Photographs of the oldest preserved Orthodox sacral buildings have been taken during the fieldwork of 2007-2010.
\end{abstract}

Key words: Estonia, Orthodoxy, Orthodox sacral buildings, poluverniks, Setomaa (Setoland), Seto tsässons

This article provides an overview of Russian Orthodoxy and its churches, priories and chapels in Estonia, from the earliest known dates in the 11th century to the 1840s when massive numbers of Estonians started to convert to Russian Orthodoxy. The movement, from the Lutheran to the Russian Orthodox Church in the southern Estonian counties, started in 1845. Until then, Orthodoxy was mainly the religion of the local Russians and Seto people, and remained influential among the poluverniks of eastern Estonia, the Russians who blended with the Lutheran Estonians.

The first sub-chapter describes the distribution of Orthodoxy and the construction of its sacral buildings in the present-day territory of Estonia and Setomaa (Setoland), from the 11th century to the end of the Swedish era, when the prevalent Christian confession in Estonia was Lutheranism (preceded by Roman Catholicism). The second sub-chapter will examine the construction of Orthodox churches since the beginning of the 18th century, when the Estonian territory was conquered by Russia during the Great Northern 
War, and the Russian Orthodox Church became free to establish its churches in Estonian towns. No thorough studies of Orthodoxy, or its sacral buildings from the beginning of the 18th century through the $1840 \mathrm{~s}$, have previously been published, either by Estonian historians or by authors writing from the Orthodox point of view. ${ }^{1}$

Therefore, the current article pays more attention to this period, as well as to the Orthodox churches of the time, which are the oldest surviving Orthodox religious places of worship in Estonia, with the exception of the oldest churches and tsässons (Seto Orthodox chapels) that have been preserved in Setomaa and were built during the 14 th-17th centuries.

The history of the Old Believers (living in Estonia since the end of the 17th century), who were the followers of Russian Orthodoxy, prior to the reforms by the Patriarch of the Russian Orthodox Church Nikon in the 17th century, is not dealt with thoroughly in this article. ${ }^{2}$ Suffice it to say that the Old Believers started to build their houses of prayer and skeets (convents) since the 18th century. ${ }^{3}$ The Unified Church (Edinovertsy, Russian: единоверцы, i.e. 'coreligionists'), which tried to bring the Old Believers back to the Orthodox Church, is also not discussed here. ${ }^{4}$

In addition to the Orthodox sacral buildings, this article provides an overview of how widely Orthodoxy spread among Estonians and the local Russians, as well as among the poluverniks of eastern Estonia. Likewise, the article also describes Orthodoxy in Setomaa, an area which was partially or wholly incorporated into Russia for centuries (specifically as a part of Pskov), prior to accession with the Estonian territory in 1920, and therefore under the direct influence of Orthodoxy, unlike the rest of Estonia. However, the Orthodoxy and sacral buildings of the Setos (such as the convents in Irboska/Izborsk, Petseri/Pechory and Mõla, as well as the churches and the tsässons) are quite different from the ones in the rest of Estonia and will be further discussed in future written works. Therefore, mainly the founding of these churches and tsässons will be discussed here, in the framework of Seto Orthodoxy.

The information, about establishing Orthodox religious buildings, is insufficient, especially regarding the early period (before the 17th century), and partly in dispute (e.g. information on the Orthodox churches that were established in Tartu in the 11th century). ${ }^{5}$ One of the aims of this publication is to present possible, but unconfirmed, information on the early sanctuaries, as a starting point for future studies. When referring to the names of the churches, the Russian style saint names are used, followed by international name forms in parentheses, where applicable.

In this article, photos will be presented of churches in Estonia and the Petseri/Pechory (Setomaa) area, built during the period under discussion, as 
well as of older Seto tsässons in present-day Estonia. All of the photos were taken by the architectural photographer Arne Maasik during the fieldwork led by the author of this article in the period of 2007-2011. ${ }^{6}$

\section{ORTHODOXY AND ORTHODOX SACRAL BUILDINGS IN ESTONIA DURING THE 11TH-17TH CENTURIES}

Byzantine-Russian Orthodoxy is probably the earliest form of Christianity which reached Estonia. To some extent, the ancient inhabitants of these territories were probably first christened into Orthodoxy in the 11th-12th centuries. Therefore, it must have been before Estonia (except Setomaa) fell under the influence of the Roman Catholic Church at the beginning of the 13th century. Since the early contacts with the "Russian belief", several Old Russian loan words have entered the Estonian language (e.g. rist (in Russian Kpect): 'cross', ristima (крестить): 'baptise', рарр (поп): 'priest', raamat (грамота): 'book' and pagan (поганый): 'pagan'). These words were introduced in the Baltic-Finnic languages before the 13th century and the German conquest (Setomaa 2009: 166; Sõtšov 2004: 14; Tarvel 1987: 18-19; Sild 1931/32: 110).

The first Christian church may have been constructed as early as in the 11th century in Yuryev (Tartu), a town established by the Russian invaders. The claims of primarily Orthodox authors about two Orthodox churches being constructed in Yuryev in the 11th century are debatable, but nor is there conclusive proof against these claims. ${ }^{7}$ The feasibility of Orthodox churches, being established in the 11th century, has been confirmed by Anti Selart and Olaf Sild, scientists who have studied the early influence of Orthodoxy in Livonia. Olaf Sild, a church historian, has written about Russian estates around Tartu in the period of 1030-1061: "Probably a church or a chapel had also been built here," and the "nearby Ugalans" (residents of the Ugala district) may have been exposed to Russian church rituals and traditions. But Sild also admits that there is no Russian loan word meaning 'church' (possible sources being the Russian words храм, церковь, оr погост for a village around a church) in Estonian, although several other religious loans of Russian origin are in use. Overall, this might mean that it was too early for a church to actually be built. In the Russian provinces, the wide-scale construction of churches took place later (Sild 1931/32: 106, 112-113), and in the 11th century these territories, close to the Russian borders, were pagan in many aspects, even though Christianisation had been instituted by the authorities.

According to the existing archaeological data, the existence of a church or churches in Tartu between 1030-1061 may be assumed, but this has not been 
confirmed. ${ }^{8}$ Researchers are of the opinion that there is no continuity between the Russian settlement in Tartu in the 11th century and the medieval town of the 13th century (Tvauri 2001: 212-213, 250-254; see also Selart 2009: 283). This means that, even if there were any churches (or just one) in Yuryev in the 11th century, the buildings were probably demolished, and there is no link between these and the two Orthodox churches that were active in Tartu after the German invasion in the 13th century - namely, the churches of Nikolai (St. Nicholas) and Georgi (St. George). ${ }^{9}$

Anti Selart is of the opinion that the excavations at the Georgi (St. George's) church and in its graveyard in Tartu, as well as other archaeological finds, demonstrate that Russian inhabitants were present in Tartu in the middle of the 13th century at the latest. The Georgi (St. George's) Orthodox Church was situated in the territory of the present-day Botanical Gardens and the Nikolai (St. Nicholas') Orthodox Church near the Jaani (St. John's) Church (Selart 2009: 283-284; 2006: 18-19). Nevertheless, archaeological data do not confirm the sites of the two churches, let alone the construction work dating back to the 13 th century. ${ }^{10}$ However, by the 15 th century at the latest, these churches were present in Tartu. Written records of the two Orthodox churches in Tartu date from $1438^{11}$ and the churches were probably built considerably earlier. ${ }^{12}$ It was possible to establish churches that belonged to the merchants from Pskov and Novgorod (the Georgi Church was built by Novgorodians and the Nikolai Church by Pskovians) due to the commercial relations of these two Russian towns with Tartu and Tallinn as members of the Hanseatic League (see Selart 2006: 9-10, 18-19; 2009: 283-284).

In Reval (Tallinn) the Russian Nikolai (St. Nicholas') Orthodox Church and cemetery were mentioned in the manuscripts of the town in 1371, situated, at that time, between the Oleviste (St. Olaf's) Church and the town wall (Kleinenberg 1962: 242; Berens 1974: 363). The new Church of St. Nicholas, probably built by Novgorodians, was mentioned in written sources from 14211422 as being already at its present location in Vene (Russian) Street ${ }^{13}$ (Kangropool \& Bruns 1972: 14). According to sources from the 15th century, the church belonged to Novgorodian merchants who, along with local Orthodox priests, were persecuted by the municipality. The Nikolai (St. Nicholas') Church was a chapel for Russian merchants in the 15th-16th centuries; it was strictly isolated from the public town space and shared a roof with the storehouses used by the merchants (see Kleinenberg 1962; Selart 1998a: 68; 2009: 281-282).

According to various records, the Nikolai (St. Nicholas') Church was destroyed and rebuilt several times. At the end of the 17th century the Nikolai Church in Tallinn was the only active Orthodox church in the Estonian terri- 
tory, which was under Swedish rule at that time. The church building stood there until the beginning of the 19th century. ${ }^{14}$ Yet in Setomaa (which was Russian territory at the time), there were scores of Orthodox churches, priories and tsässons/chapels at the end of the 17th century. Of these early Orthodox buildings (built during the 14th-17th centuries) the ones that have been preserved, in the Pechersky District, are the two Nikolai (St. Nicholas') Churches and the Church of the Nativity of the Mother of God in Irboska (in Seto/Estonian language, Izborsk in Russian), the church on the island of Kulkna (Kolpino in Russian), the Mõla (Maly in Russian) priory (in ruins) and church, the Senno and Tailova churches and several churches in the Petseri (in Russian Pechersky, Pskovo-Pechersky) Monastery.

The oldest of the Setomaa churches, still intact to this day, is the Church of St. Nikolai (St. Nicholas) in Irboska (Izborsk), built in the 1340s within the Irboska stone stronghold. This is also the oldest preserved Orthodox church in Estonia within the boundaries established by the Tartu Peace Treaty in 1920. This church with its one apse, one dome and four pillars is typical of Novgorod church architecture. In the 1930s, during the first period of Estonian independence, the congregation of this church included numerous Setos and Estonians, side by side with Russians. ${ }^{15}$ The same applied to the mixed congregations of the Mõla and Kulkna stone churches, built in the 16th century, and the Tailova Church, completed in $1697 .{ }^{16}$ However, now, only Russian-speaking congregations are active there. Over the centuries, these churches, the oldest in Pechory District, have been repeatedly rebuilt and renovated, which is why they have lost some of their original appearance. ${ }^{17}$

The Orthodox Church mission may have reached Setomaa as early as in the 11 th or 12 th century. If we are only able to make assumptions about the influence of the earlier Orthodox churches and monasteries with regard to spreading the religion among the non-Russian-speaking people of

Photo 1. The Church of Nikolai (St. Nicholas) in the Irboska fortress (in the Pechory District of the Pskov Oblast of the modern Russian Federation). Photo by Arne Maasik 2008.

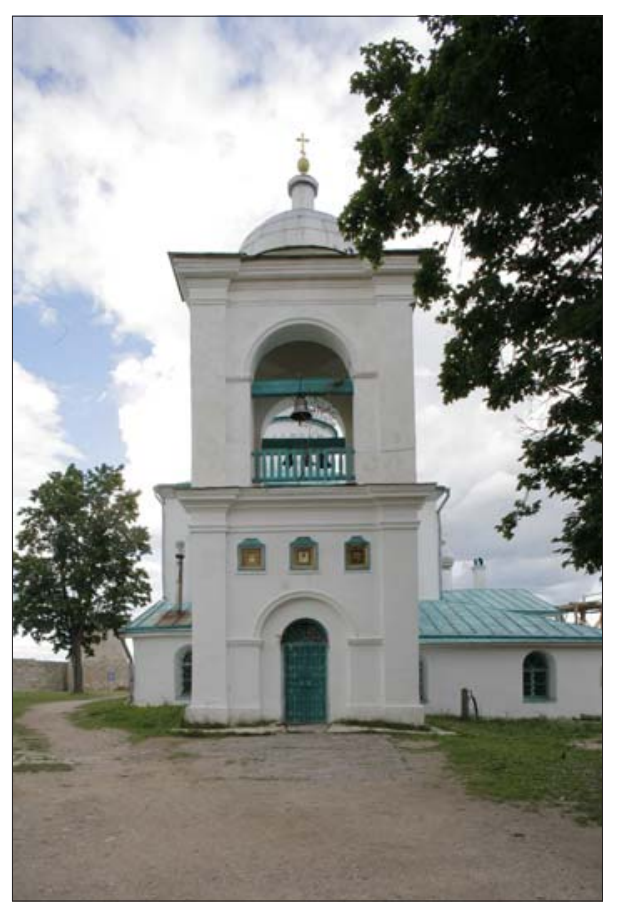


Setomaa, the role of the Petseri (Pechersky) Monastery certainly cannot be underestimated. The cave Church of the Dormition of the Mother of God was consecrated in 1473, which is considered to be the year of establishment for the Petseri (Pechersky) Monastery.

Over the centuries, the Pechersky Monastery became the spiritual centre for not only the Russians in the Pechory Region, but also for the local Seto people. There are good reasons to talk about the increasing influence of the Pechersky Monastery and with it, the Orthodox religion, among the Setos since the $1520 \mathrm{~s}$ - this is when the Pechersky Monastery became a special site for pilgrims, largely thanks to the famous Mother of God icon of Pechory.

In addition to the Pechersky Monastery, the Mõla (Maly) Monastery may also have contributed to spreading Orthodox religion among Setos in the 16th century. Some researchers claim that the Mõla Monastery played a vital role in Christianising the natives of Eastern Setomaa (see Setomaa 2009: 240). A Monastery of the Nativity was founded in Mõla in the middle of the 16th century (according to folk tales, the monastery was already established in the 1480s by St. Onufri of Mõla). The stone buildings, partially preserved, were constructed in the mid-16th century, and the Church of the Nativity, still standing to this day, was probably built as early as before the Livonian War. Most of the monastery buildings were destroyed in 1581 by the army of the Polish king Stephen I Báthory. ${ }^{18}$

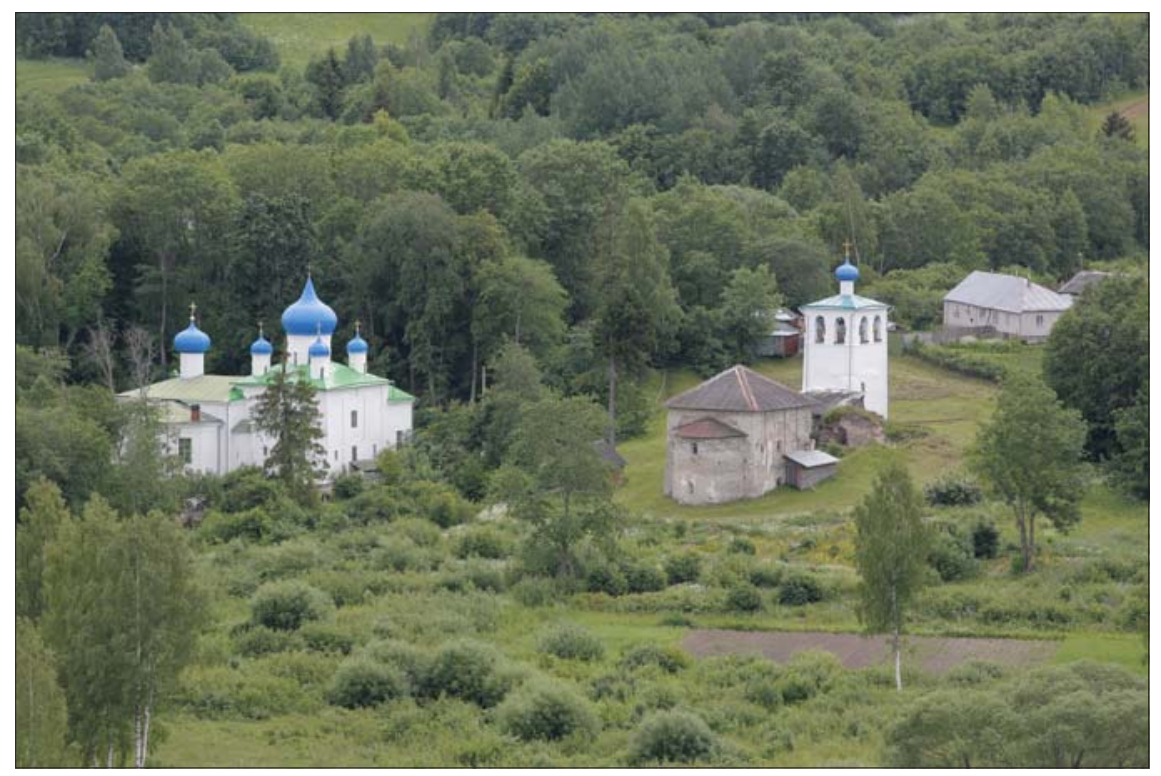

Photo 2. The Church of the Nativity in Mõla (Maly), built in the mid-16th century. The bell tower and ruins of the Monastery of the Nativity in Setomaa. Photo by Arne Maasik 2008. 
Since the 16th century, churches have also been established in the areas chiefly inhabited by Setos. The first historical records of the Värska Orthodox Church in Setomaa date back to as early as the end of the 16th century. The old wooden church in Saatse was completed in 1673 and the Saatserinna congregation is first mentioned in 1763 (Kiristaja 2005: 30; Setomaa 2009: 288, 329). The 16th-18th century wooden churches of Värska and Saatse have not preserved until today. ${ }^{19}$

As a result of the activities of the Pechersky and Mõla monasteries, as well as those of various churches, it is possible that Orthodoxy was quite widespread in Setomaa by the 17th or 18th century (and maybe even in the 16th century). During the 17th and 18th centuries and from thereon, the Seto Orthodox religion remained a mixture of the old religion or "Seto religion" and the Orthodox religion (especially its cult of saints). ${ }^{20}$

Besides the Orthodox churches and the Pechersky and Mõla monasteries, the Orthodox cult in Setomaa was practised in homes, natural places of worship and village chapels, known as the Seto tsässons (in Russian часовня). Most of the tsässon s were erected upon the initiative and at the expense of the local inhabitants and were dedicated to a specific Orthodox Church holiday or saint, after whom the tsässons have been named. ${ }^{21}$ Annual, or semi-annual, larger get-togethers and church services were held by priests on the day of the respective saint and church holiday. For the rest of the year, the locals have used the tsässons for praying or funeral ceremonies.

The oldest preserved tsässons, within the Estonian territory of Setomaa, are those of Mikitamäe (probably completed in 1694, according to the dendrochronological dating method), and Uusvada tsässon (probably in 1698) (see Läänelaid \& Raal \& Valk 2005). Some of the tsässons in the Pechory District of Pskov Oblast are even older.

Mikitamäe Toomapühapäeva tsässon is also the oldest wooden sacral building in continental Estonia (Ruhnu Lutheran Church, the oldest wooden sacral building on the Estonian islands, dates from 1644). Toomapühapäev (in the Seto language Tuumapühäpäävä or Ollôtuspühä or kôllapühäpäävä or väiko lihavõodõ), the holiday of the tsässon, is celebrated a week after Easter. The Mikitamäe tsässon, relocated and left to decay during Soviet times, was once again relocated, restored and consecrated in 2009. The Uusvada village chapel in present-day Meremäe rural municipality is the second oldest tsässon within the Estonian territory of Setomaa. According to lore, the tsässon of Uusvada belongs to Anastasia (in the Seto language Nahtsi), whose day is celebrated in Setomaa on November 11. ${ }^{22}$ There are also several other Nahtsi tsässons in Setomaa. 


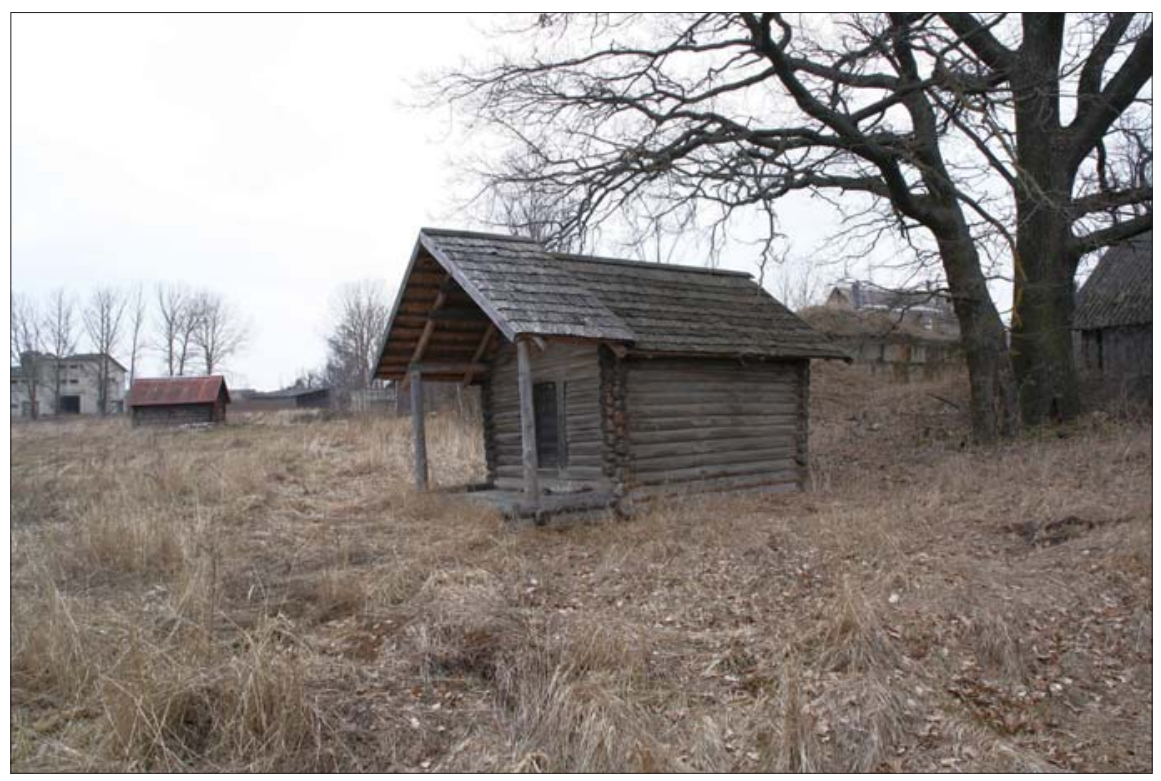

Photo 3. Mikitamäe Tuumapühäpäävä (in Estonian Toomapühapäeva, for Setos also ollõtuspühä or kõllapühäpäävä or väiko lihavõõdõ) tsässon. According to dendro-dating, the oldest tsässon, preserved within the Estonian territory of Setomaa, built probably in 1694. Photo by Arne Maasik 2008.

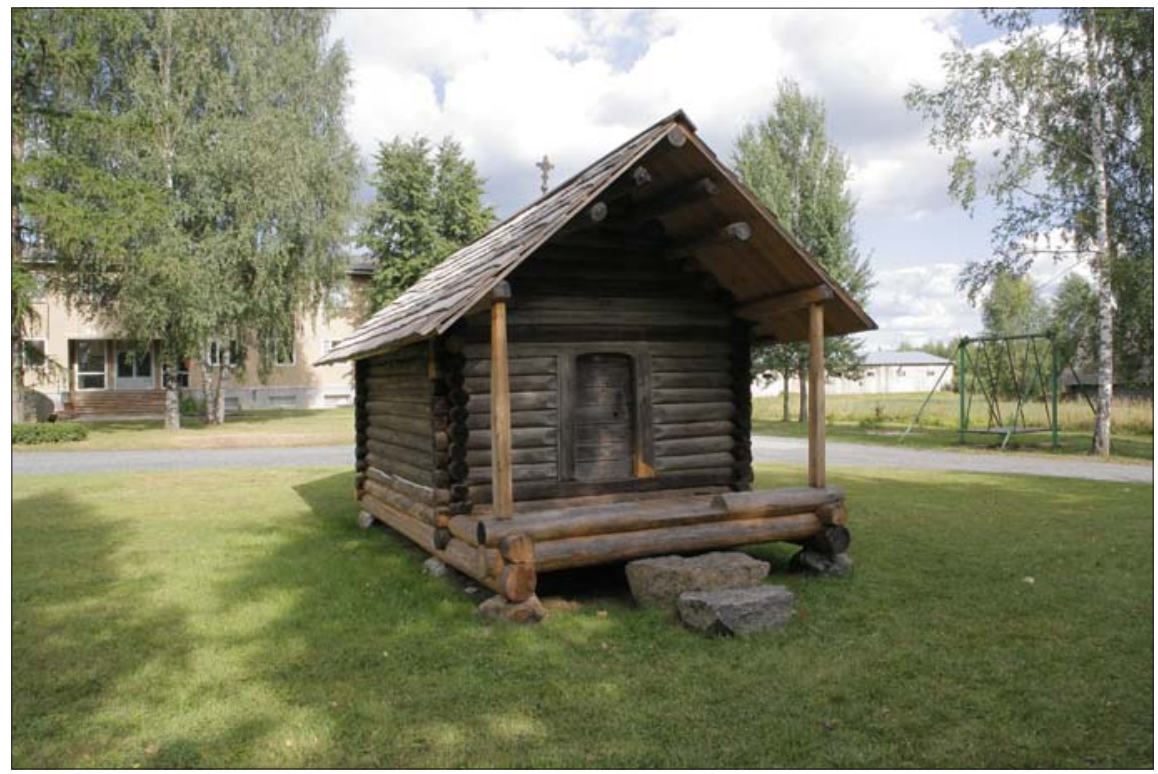

Photo 4. Mikitamäe Tuumapühäpäävä (Toomapühapäeva) tsässon after restoration in 2009. Photo by Arne Maasik 2010. 
From Setomaa, the Orthodox Church mission spread to other parts of Estonia. The Pechersky Monastery is associated with the next wave of Orthodoxy to come into the Estonian territory during the Livonian War (1558-1583). Igumen Kornelius, the head of the convent from 1529 to 1570, had a special status in disseminating Orthodoxy among the Seto, and to some extent among Estonians as well. According to folk tradition and chronicles, Kornelius headed the campaign to construct churches for local residents who had converted to Orthodoxy, not only in the Pechersky District, but also in the present-day Võru County, next to historical Setomaa. About the widespread Seto legends of the Igumen Kornelius, or the Pechoran Strongman, see Muistendid 1963: 315ff.

In present-day Võru County (Estonia), in the vicinity of Vastseliina, Kornelius established the Church of the Nativity of the Lord in Tabina and the Church of the Trinity in Hagujärve (Kirikumäe) before 1570, during the first half of the Livonian War. It is possible that Kornelius also played a decisive role in founding an Orthodox church in the present-day Valga County, near Lake Aheru. ${ }^{23}$ The churches for the newly christened Estonians and Seto were provided with clergymen, church attributes and financial support. Kornelius' wish to spread Orthodoxy among Estonian peasants has also been mentioned in the priory's writings (Setumaa 1928: 356-357; Kase 1999; EÕK 2007: 58-60; Tihhon 2007: 20; Setomaa 2009: 243).

Kornelius and his assistants were active in Estonia during the Livonian War, taking advantage of the advance of the Russian troops. In 1558, the Russian forces invaded Vastseliina, the main centre near the border of Old Livonia, which enabled them to build Orthodox churches in the surrounding areas. An Orthodox church was also probably constructed in Vastseliina. The churches in Tabina and Hagujärve (in the later Vastseliina parish) were probably destroyed by the end of the Polish-Swedish wars. There are records from 1638 that mention them as being in ruins. The icons were taken to the Pechersky Monastery when Russia was defeated in the Livonian War (Selart 1998a: 70, 1998b: 24; Setomaa 2009: 243, 455). ${ }^{24}$

In addition to the churches founded by the Pechersky Monastery, Russians constructed churches in several Estonian towns and settlements, as well as in some frontier regions in the countryside, after conquering the greater part of Medieval Livonia (Selart 2006: 9; Setomaa 2009: 243). In the invaded territories, the Tartu (Yuryev-Viljandi) Bishopric was founded, probably in $1570 .{ }^{25}$ The churches were mostly built to suit the needs of the military and the gentry serving the Tsarist government. In 1581, the Swedish king told his military chiefs to have mercy on the Russian churches and priories that were especially numerous around Tartu (Aleksius II 2009: 92). Not much information has been preserved about these, often field churches for the troops, and 
buildings temporarily used as churches. What is known, however, is that in Tartu there were several churches and at least one Orthodox priory (according to Balthasar Russow, there were at least two convents at the time of the Swedish military campaign in 1578 - Russow 1993: 303). ${ }^{26}$

In Narva, two churches were founded (one in the Ivangorod stronghold and the other in the town of Narva), by the orders of Ivan IV, after the town had been conquered by the Russians in 1558 . Those churches were active until the Swedish conquest in 1581 (Ivask \& Sinjakova 2005: 10-11). In 1558, Russians also built an Orthodox church in Vasknarva, where an Orthodox Russian community might have existed previously. The Holy Trinity Church in Vasknarva existed for some time under the Swedish reign (Liiv 1928: 16, 73-74; Moora 1964: 44; Selart 1998a: 69-70).

After the Russian defeat in the Livonian War and the armistices with Poland and Sweden, the Estonian territory was divided between Poland and Sweden. Most Russians left and the churches were either demolished or just gradually deteriorated. Still, in several places the Russian churches survived for some time at least. In Viljandi, there were two Russian Orthodox churches in 1599, probably built during the Livonian War, which were used by Lutheran and Catholic congregations. ${ }^{27}$ In Vastseliina, the Russian priests had even been paid for work on the churches during the first decade of the Polish reign (Selart 2006: 21).

The ruins of the medieval Church of Nikolai (St. Nicholas) in Tartu were still present at the beginning of the 17 th century, when the Swedish authorities returned the ruins to the Russian community that had survived in Tartu, but they were unable to reconstruct the church (see Berens 1974: 393). However, there are reports from the Swedish period of the construction of an Orthodox church in Vastseliina. As it happens, the Russians had burnt down the Lutheran church of Vastseliina during the Russian-Swedish war that lasted from 1656 to 1661, and had built an Orthodox church in front of the Vastseliina stronghold. This building, called a "Moscovite tavern", was used as a Lutheran church after the war (see Kõpp 1959: 97; Setomaa 2009: 455).

In addition to Orthodox churches built in Tartu, Tallinn and elsewhere in Estonia during the Livonian War, churches also appeared in the EstonianRussian borderlands and in Virumaa (mainly in present-day East Viru County) during the 16th century at the latest. The Russian community in East Viru County has a long history and the Orthodox creed was present quite early in this Estonian region. According to Aliise Moora, the Novgorodian and Pskovian priests might have christened the Russian-Votian population of the Alutaguse region as early as the 13th century, whereas the Narva River started to function as a distinct borderline since the 13 th and 14th centuries (1964: 38). 
By the 16th century at the latest, the River Narva had become the border that separated the Orthodox and Roman Catholic worlds, but there were still some Orthodox Russians on the western bank and probably some Votians, as well, who had converted to Orthodoxy. In 1492, the Russians built the Ivangorod stronghold on the eastern bank of the river, where there were also some Orthodox churches built by Novgorodians. According to one opinion, the Church of the Dormition of the Mother of God may have been erected in the stronghold as early as at the end of the 15th century, but by other assessments this took place in the 16 th century. ${ }^{28}$

In the 16th century, the legend began to spread, of the revelation of the Mother of God in Kuremäe, and of the miracle-working icon of the Dormition of the Mother of God, which was supposedly found at the revelation site. According to one widespread version, the local Russian peasants had built a small wooden chapel during the second half of the 16th century, at the same place on Püha ('sacred') Hill, the name of which was later changed to Pühtitsa (see Liiv 1928: 71ff; Pjuhtitskii 1991: 3). The historian Otu Liiv doubts that the chapel was built in the 16th century on this hill, regarded as sacred also by Estonians, and has offered several versions of the legend of how the Mother of God icon was found by Estonian peasants (1929: 71-72).

Metropolitan Kornelius of the Estonian Orthodox Church of the Moscow Patriarchate has written about this particular event as follows: "After being given the heavenly gift - the miracle-working icon - the devout Orthodox peasants from around Pühtitsa built a chapel on the lower terrace of the Sacred Hill of the Mother of God, in which the icon bestowed on them was placed.... During those restless and troublesome years and in times of disorder and wars, the local people protected the holy icon of Pühtitsa by always restoring the destroyed chapel." ${ }^{29}$ Recurrent destruction and reconstruction of the chapel was also noted by the Patriarch Aleksius II in his monograph (1999: 120), where he seems to refer to the time of the Swedish reign following the defeat of Russia in the Livonian War, the period that lasted until the Swedes were defeated in the Great Northern War, which broke out in 1700 .

Sources that mostly originate from the Lutheran Church affirm that, during the Swedish reign, crowded meetings were held around the Pühtitsa chapel every year on the 28th of August, the Day of the Dormition of the Mother of God according to the old calendar (Liiv 1928: 81; Pjuhtitskii 1991: 3). Those who convened around the chapel and reconstructed it after several devastations were probably local Orthodox Russians. The crowd gathered at the chapel on the Day of the Dormition of the Mother of God comprised people from several parishes and even from Russia, despite prohibition and threats. ${ }^{30}$ The gatherings were especially large during the 18th and 19th centuries and, at least by 
that time, there were also many Estonians among the prevailingly Russian crowd around the Kuremäe (Pühtitsa) chapel. ${ }^{31}$ Estonians had probably attended these events even earlier, during the 16th and 17 th centuries. The chapel was active in Pühtitsa until the 19 th century. ${ }^{32}$

Claims have been made that the Swedish authorities also used their soldiers to wreck Orthodox chapels in Vaivara, Jõhvi and elsewhere in presentday East Viru County (Aleksius II 1999: 120). Otu Liiv has noted a complaint from the Lutheran pastor of Jõhvi from 1652, which said that, in addition to the Kuremäe chapel, the Russians held their rites near the old chapel in the village of Lähtepää in the territory of the Illuka manor, as well as near the Maarja (Mary) chapel in Viru-Nigula (Liiv 1928: 81-82).

The ruins of the Viru-Nigula Maarja chapel, which was situated in presentday West Viru County and was shaped like a Greek cross, the only building of this kind from the Catholic period in Estonia (Tamm 2001: 21), supposedly date back to the 13 th century. The ruins have also been associated with Russianstyle church architecture. To assume that the chapel was Orthodox in the beginning might prove premature as the construction history of this sacral building has not been researched by way of archaeological means. Villem Raam has written that the plan of the chapel resembles the small church type of central Russia which developed at the beginning of the 13th century (Eesti arhitektuur 3... 1997: 162-163).

During the same period, when Estonians assumedly attended the Orthodox gatherings of the 17th century, some of the Russians of the East Viru County converted to Lutheranism. The Orthodox Russians started to call these converts poluverniki or poluvertsy (half-believers) for, despite attending Lutheran churches and becoming members of Lutheran congregations, some of them also followed many of the Orthodox rites. ${ }^{33}$ Those were the (partly) Estonianised Russians who lived in the territory between the River Narva and the northern bank of Lake Peipsi, and who had probably been living there as early as since the 13 th century. ${ }^{34}$ During the Swedish reign in the 17 th century, most of the Russians in the Iisaku area converted to Lutheranism and were Estonianised over a period of time, despite the later attempts of the Russian government to re-Russianise them. Only the population of the lakeside villages remained Russian-speaking (Kurs 2006: 102). According to Otu Liiv's study, the Russianspeaking population of south-eastern Alutaguse (Vasknarva area), especially of the villages by the River Narva, remained only formally Lutheran during the 17th century (as they were the members of the faraway Narva and Vaivara Lutheran congregations), for there was no local Russian-speaking pastor. The people of this area attended an Orthodox church on the opposite bank of the River Narva, or had priests come to them. According to the records of the 
Jõhvi pastor Thomas Kniper, by 1698 there were villages in this area which had no official coverage by any church and where the Russians had built their own chapel, which was presided over by an Orthodox priest from the opposite bank of the river. At the end of 17 th century, Orthodox practices were quite widely followed in this area (Liiv 1928: 74ff, 86-87, 124). The Estonianisation process for some of the Orthodox Russians probably started during the Lutheran Swedish era and was even more active during the reign of Orthodox Russia, during which the Tsarist government guaranteed the local Lutheran church its former leading position among the peasantry.

\section{ORTHODOX CHURCHES IN ESTONIA FROM THE BEGINNING OF THE 18TH CENTURY UNTIL THE CONVERSION MOVEMENT OF THE 1840S}

Based on the above information, speculations can be made that, by the end of the Swedish reign, some Orthodox influences from Setomaa in southern Estonia and from the Russian communities in eastern Estonia might have spread among the Estonians. But these influences were probably still weak, with the exception of the multi-ethnic areas in present-day East Viru County. After the Great Northern War, which started in 1700, Orthodox Christianity began to spread more widely again, along with the Russian conquest of Estonia. Nevertheless, the dominant faith, within the Estonian territory conquered by Russian forces, was still Lutheran, the rights and privileges of which were declared by the Uusikaupunki Treaty in 1721. At the same time, a free and unhindered spread of Orthodoxy was also taking place in the Baltic lands. Regarding the Lutheran Church, the Swedish church law applied in Estonia until 1832. Although the dominion of the Lutheran Church was restricted by several provisions enacted by the Tsarist government in order to protect the interests of Orthodoxy, it remained remote to the Lutheran peasantry, who were mostly under the influence of German landlords, until the massive conversion of Lutherans to Orthodoxy in southern Estonia that took place in the 1840s. Until then, Orthodoxy was mainly the religion of the Russians living in the Estonian and Livonian provinces, and over time it also became more and more the religion of the members of the Seto population who had remained within the borders of the Pskov (Russia) Province. At the same time, the influence of the Orthodox Church grew in the larger communities of Estonia, and scores of new churches and chapels were built even before the conversion movement that began in $1845 .^{35}$ 
When the Great Northern War started, the number of Orthodox sanctuaries began to increase in connection with the arrival of Russian forces. At first, the invading Russians took over the Lutheran (formerly Catholic) churches and re-designed them as Orthodox churches (e.g. in Narva, Tartu, Pärnu and Tallinn) or established temporary premises for Orthodox services. In Tartu, the Jaani (St. John's) Church was taken over by the military after the capture of the town in 1704, and Orthodox services were held there (Aleksius II 2009: 114). In Narva, Orthodox services were held from 1704 to 1708 in the Dome Church, which was transformed into the Orthodox Church of Alexander Nevsky, but had formerly belonged to the Swedish congregation. ${ }^{36}$ Tsar Peter the Great attended the sanctification of the Jaani (St. John's) Church as the Church of the Transfiguration of the Lord in 1708; the Jaani Church, built in the 15th century, had belonged to the German congregation until the Russian conquest in 1704 . The church was active as an Orthodox main church until its demolition in the bombing of $1944 .{ }^{37}$

Soon some new churches were built as well. In 1704, a wooden Church of the Mother of God was built in Tartu on the site of the former Church of Nikolai (St. Nicholas), as well as the Georgy (St. George's) hospital church, the fate of which is not known (Berens 1974: 394).

After the end of the war in the Estonian territory, when Estonia was incorporated into the Russian Empire in 1710, Orthodox congregations were formed and churches were built in the Estonian and Livonian provinces, but mainly for the Russians living in the towns. In addition to the Tallinn-based Nikolai (St. Nicholas') Church ${ }^{38}$, which had survived the Lutheran Swedish reign, Orthodox services were also held in other (former) Lutheran churches of Tallinn: from 1710 to 1716, in the Mihkli (St. Michael's) Church in Rüütli Street and, starting from 1716, in the medieval main church of the former Roman Catholic (Cistercian) Convent (in Suur-Kloostri Street), which had been the St. Michael's Church for the Swedish military forces during the Swedish rule. The latter was sanctified as the Church of the Transformation of the Lord, after renovation in 1734, and served as the main Orthodox church until 1900, when this status was given to the newly-built cathedral of St. Alexander Nevsky. The iconostasis of the Church of the Transformation of the Lord (by I. P. Zarudnyi) was made in 1718-1719 ${ }^{39}$; the tower was erected in 1776, and the present-day windows, main entrance and cupola were completed during 1827-1830.

There were new churches built as well, at first mostly for the military. The garrison church of the Nativity of the Mother of God (Kazan Icon) in Tallinn was constructed and sanctified in 1721 . The wooden church in present-day Liivalaia Street is the oldest preserved Orthodox church in Estonia (not counting the sanctuaries in Setomaa) and the oldest wooden sacral building in Tallinn. 


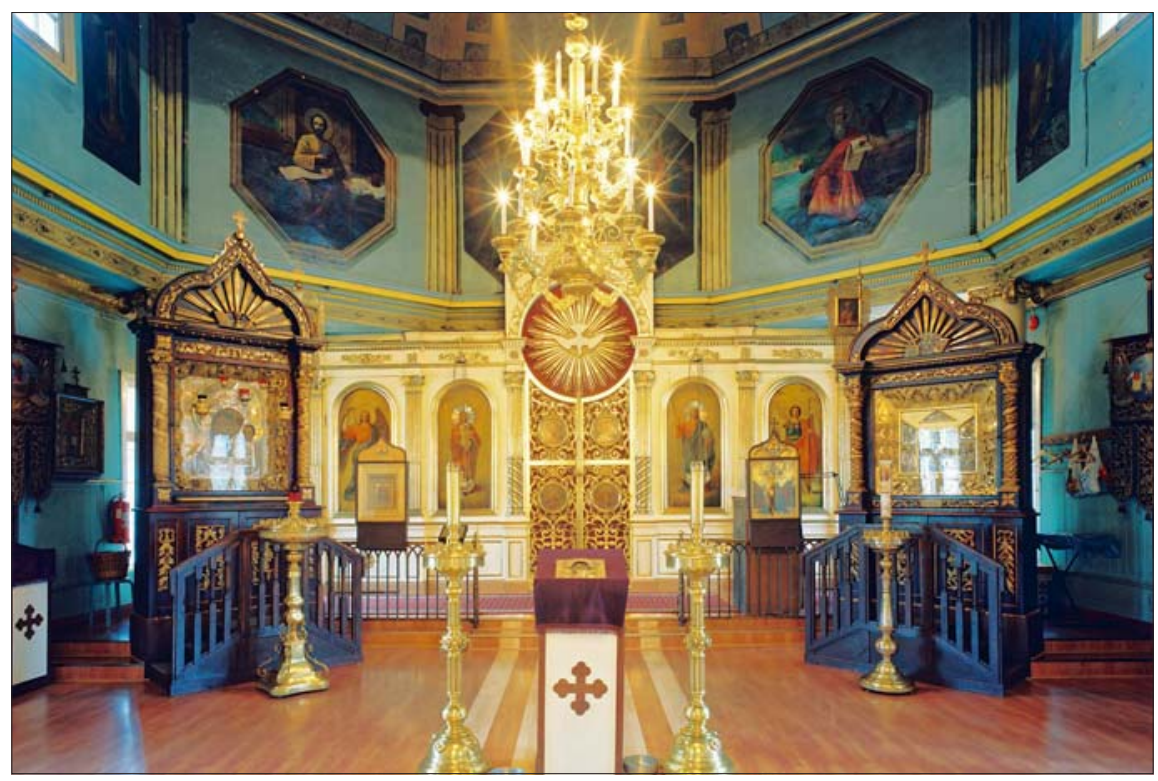

Photo 5. The Church of the Nativity of the Mother of God (Kazan Icon) in Tallinn (consecrated in 1721). Photo by Arne Maasik 2009.

The church was reconstructed in the first half of the 19th century: the building was covered with wood boards and both the interior and the exterior were given a period-specific Neo-classicist appearance. ${ }^{40}$ By 1734, the Church of Teodoros (St. Theodore) the Commander was built in Tallinn and existed until 1842 (EÕK 2007: 26, 40; Berens 1974: 351, 369).

The second oldest building in Tallinn, specifically built as an Orthodox church, was erected near the port by Russian naval forces during $1752-1755$, on the ruins of a sunken ship, according to the relevant inscription. The Church of St. Simeon and the Prophetess Hanna, initially used as a naval church, was repeatedly reconstructed and remodelled; the building obtained its present-day size, cross-shaped ground plan and Historicist façade with wooden décor in 1870. The later history of this church is one of the most interesting among the Orthodox churches in Estonia - it was damaged and turned into a gym during the Soviet era, but reconstructed again as an Orthodox church at the beginning of the 21st century. This church, situated in Ahtri Street, was sanctified in 2007 as the main church of the Estonian Apostolic Orthodox Church. ${ }^{41}$

Several Orthodox sanctuaries were also built in Tallinn in the second half of the 18th century and in the first half of the 19 th century. ${ }^{42}$ Among them is the Church of Nikolai (St. Nicholas) the Bishop and Miracle-Worker, which was sanctified in 1827 and is still standing. It was built in Vene (Russian) Street 


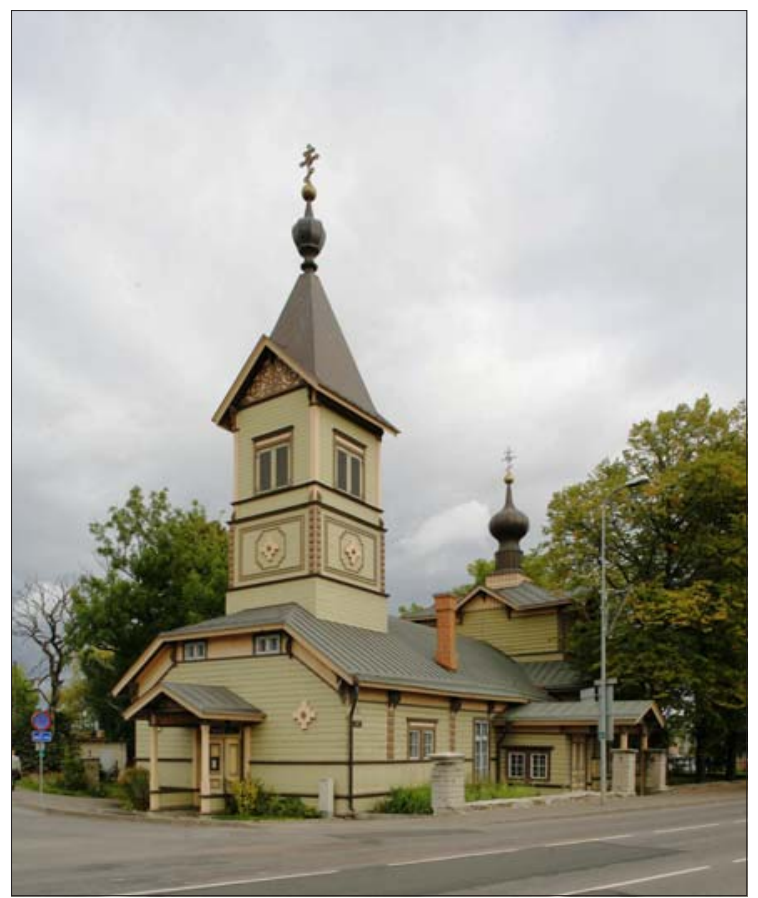

Photo 6. The Church of St. Simeon and the Prophetess Hanna in Tallinn (completed in 1755). Photo by Arne Maasik 2009.

to replace the Nikolai (St. Nicholas') Orthodox Church, which dates back to the Medieaval period and was falling apart by the beginning of the 19th century. There was a desire to build a new church as early as 1804 , but it was not built until 1822-1827; the construction was drawn out due to lack of funds. The domed church, with some Neo-classicist features, was built according to the design of L. Rusca from St. Petersburg, who was Swiss by origin (Berens 1974: 364-365; Pantelejev et al. 2002: 26-36; Tallinna 2009: 43).

The wooden church, built in Tartu by the Russian military forces in 1704, was almost in ruins by 1749. In 1752, the construction of a new church was initiated and the Church of the Ascension of Mary (according to other records, the Church of the Dormition of the Mother of God) was sanctified in 1754. Another church was built next to it in 1771, but both burned down in the fire of 1775. The new, Neo-classicist Church of the Dormition of the Mother of God (Uspensky), which is still standing, was built, according to the design of the Novgorodian architect P. Spekle, from 1776 to $1783^{43}$; in the meantime, services were held in a school building that belonged to the military forces (Berens 1974: 395; EAÕK piiskopkonnad). 
In addition to Tallinn and Tartu, new Orthodox congregations and churches were established in other towns and settlements of Estonia before the middle of the 19th century, mainly in order to serve the local Russian population (soldiers, civil servants and their families). Of the churches built in the 18th century and at the beginning of the 19th century, the ones in Pärnu, Paldiski, Kuressaare and Võru have been preserved, whereas all the churches that were built in Narva and Ivangorod around that time have been destroyed.

In Pärnu, the Jaani (St. John's) Church, which belonged to the Estonian Lutheran congregation, was taken over in 1710 to hold Orthodox services and sanctified as the Uspensky Church. This congregation was later reformed as the Katariina (St. Catherine's) congregation. Probably shortly after that, in 1710, a new Alexander Nevsky garrison church was built. In the 1740 s, this wooden church was replaced with a new wooden one, which stood from 1749 to 1791.

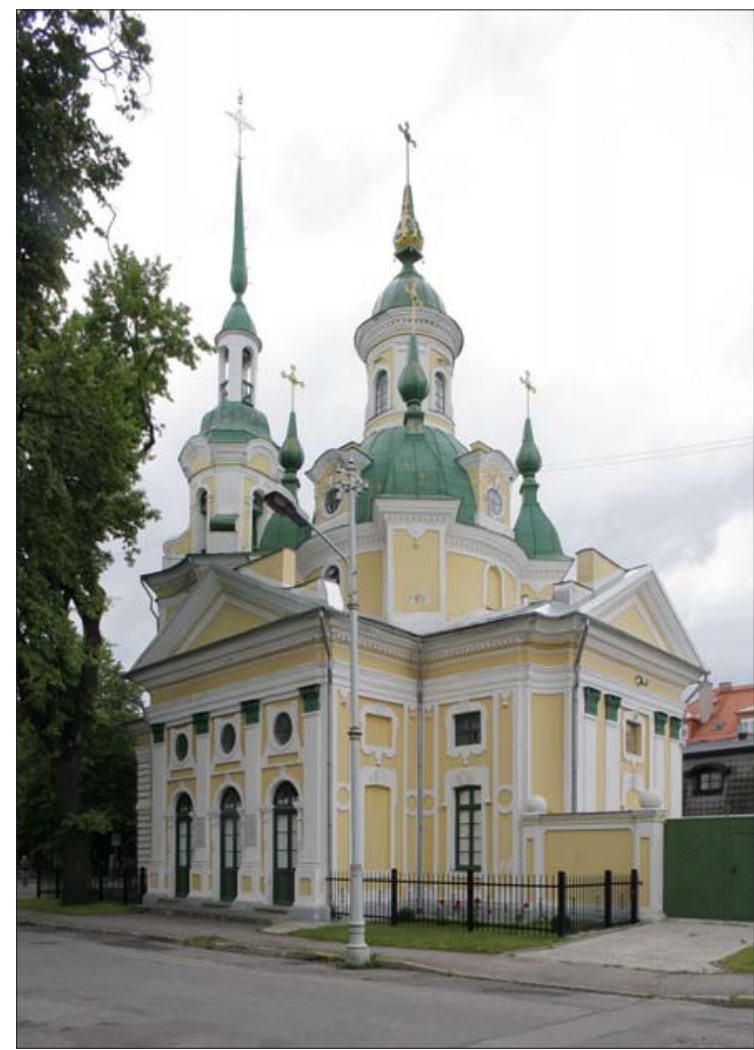

Photo 7. The Church of St. Catherine the Great Martyr in Pärnu (consecrated in 1769). Photo by Arne Maasik 2009. 
The building of an Orthodox stone church, which is still standing, was commissioned and funded by Tsarina Catherine II, who visited Pärnu in 1764. The church, designed by architect P. Yegorov (1764-1768) and sanctified as the Church of St. Catherine the Great Martyr in 1769, was built in the Baroque style and, according to the opinion of many art historians, is the most stylish and lavish Baroque church in Estonia. It was the first Orthodox church to be built in the Baroque style in the Baltic area (Pärnumaa 2001: 17; Berens 1974: 305-306; EÕK 2007: 54; Aleksius II 1999: 143).

In 1721, a tent church was erected in Paldiski, in the settlement at the port established by Peter the Great, for Russian soldiers and workers (including convicts) sent from Russia to work on the building of the port and its fortifications. In 1728, a wooden church was built for them and, from 1784 to 1787, the new Church of St. George, after the design of J. Moor, was also built. The exterior of this stone church was clearly European. The Orthodox congregation of Paldiski is one of the most intriguing in the history of Estonian Orthodoxy, considering its national composition (Old Believers, or starovers, and other descendants of convicts, as well as Estonian Swedish inhabitants) and historical background. ${ }^{44}$

Following the incorporation of the island of Saaremaa into the Russian Empire in 1710, an Orthodox community of Russians also formed on Saaremaa,

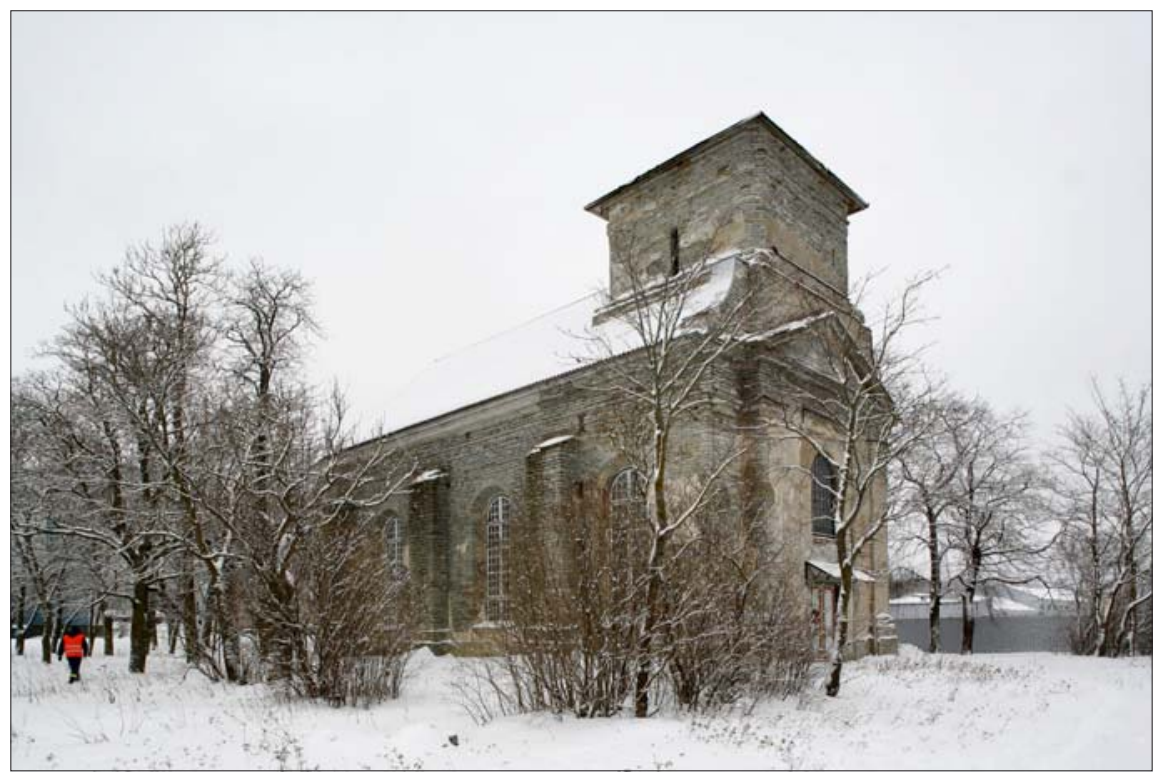

Photo 8. The Church of St. George the Great Martyr in Paldiski (consecrated in 1787). Photo by Arne Maasik 2009. 
which was later to become the main centre of Estonian Orthodoxy. ${ }^{45}$ Prevailingly, the Orthodox community comprised soldiers from the Russian garrison in Kuressaare and Russian officials, tradesmen, craftsmen and their families. Until the middle of the 18th century, there was neither a resident Orthodox clergyman on Saaremaa nor a congregation. Orthodox believers had their children baptised and their weddings carried out by a Lutheran pastor. The Orthodox tradition of anointing children was probably carried out later, when an Orthodox priest visited the island. Lutheran pastors also held Orthodox services elsewhere in Livonia and Estonia (Aleksius II 1999: 148-149), due to the lack of Orthodox priests.

It was only in 1747 when a congregation was established in Kuressaare (Arensburg), after an urgent plea from the local Orthodox believers and pursuant to the order of Tsarina Yelizaveta, when a resident priest was allotted to them. At first, they used a military field church, but in 1749 the wooden Church of Nikolai (St. Nicholas) was built in the stronghold of Kuressaare, where services were held until the completion of the current stone Church of St. Nicholas in $1789 .{ }^{46}$

In Narva and in Ivangorod, the latter of which is situated on the east bank of the Narva River, four Orthodox churches were built during the 18th century, three of them in Ivangorod (Jaanilinn). Three were initially regiment churches and one a garrison church (Ivask \& Sinjakova 2005: 14-15). New congregations were established, in addition to the aforementioned Narva congregation of the Transfiguration of the Lord. All of these churches have been destroyed..$^{47}$

In the town of Võru, a congregation consisting of Russians was established in 1793. The stone Church of St. Catherine the Great Martyr, built from 1793 to 1804 (with intervals), ${ }^{48}$, was in early Neo-classicist style, with some Baroque elements, and probably designed by Matthias Schons, the province architect of Livonia; the master builder was a local inhabitant, Johann Karl Otto. The building is a fine example of early Russian provincial Neo-classicism, following the Western European examples built in St. Petersburg (Berens 1974: 95-96; Aleksius II 1999: 149; EAÕKi piiskopkonnad).

Prior to the 1840s, Orthodox churches were also built for Russians living in smaller country settlements of Estonia - the ones in Nina and Räpina have survived, but the wooden church in Vasknarva and the first Orthodox church of Mustvee have been destroyed. ${ }^{49}$ These churches, built in the Russian-inhabited areas on the shores of Lake Peipsi, were probably also meant to act as counterweights to the local Old Believers' chapels erected in these areas during the 18 th and 19 th centuries. 
The Church of the Protection of the Holiest Mother of God was built in the village of Nina, the main population centre of the Old Believers, situated on the shore of Lake Peipsi. The village of Nina is the also oldest surviving village of Orthodox Russians on the western shore of Lake Peipsi, and was probably founded in the 17th century (Moora 1964: 60). By the time the church was built, Nina was the only almost exclusively Orthodox village in the region predominantly inhabited by Old Believers. Previously, the sparse Orthodox population had been without a church of their own. The congregation of Nina was established in 1824 and the church was designed by G. F. W. Geist, a master builder from Tartu (Tohvri 2004: 56). Construction work took place from 1824 to 1828, and the church was erected on a plot bestowed by Baron Stackelberg. The construction was funded by the state with the help of private donations, including those from local Lutheran landlords. ${ }^{50}$

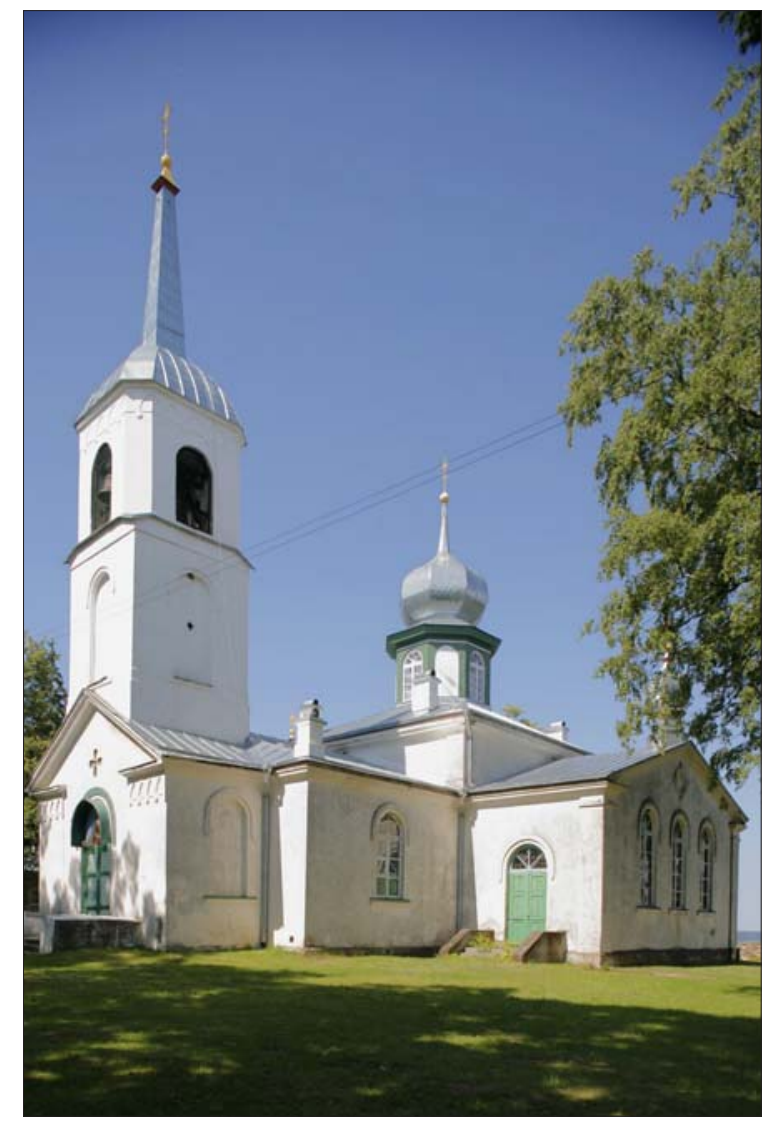

Photo 9. The Church of the Protection of the Holiest Mother of God in Nina (consecrated in 1828). Photo by Arne Maasik 2008. 
In the manor of Räpina, an Orthodox church was built, by order of Tsarina Yelizaveta, in 1752. The wooden church served the Russian workers brought in from Russia to work in the local paper mill. It burned down in 1813 and the congregation moved into a wooden house of prayer. In 1827, Tsar Nikolai I ordered a new stone church to be built and granted 20,000 roubles for that purpose. The independent congregation was re-established in 1828. The Church of St. Sakarias and St. Elizabeth was constructed after a design by G. F. W. Geist in 1829-1833. ${ }^{51}$

Of the churches that have not been preserved, the wooden church of Vasknarva ${ }^{52}$ was probably built in the period of 1817-1818; the miraculous icon of the Dormition of the Mother of God was brought to the church in 1818. Previously, the icon was kept in the Pühtitsa chapel, built at the site of the icon's discovery. Pühtitsa was one of the most important sanctuaries for Orthodox Russians living in Estonia and farther away. Metropolitan Kornelius has written: "For safety, the holy icon was sometimes kept in Narva as well, but when a church was built in Vasknarva, the chapel of the Dormition of the Mother of God was affiliated with it and the miraculous icon was transferred to the church."53 The tradition to hold an annual procession on the Day of the Dormition of the Mother of God, in order to take the icon from the Ilya/Eelija (St. Eliah) Church in Vasknarva to the Pühtitsa chapel some $30 \mathrm{~km}$ away, commenced after 1818. ${ }^{54}$ Metropolitan Kornelius has reflected the memories of the participants who attended the procession in the 19th century: "The procession was onerous. There was no proper road from the village of Vasknarva to Pühtitsa, only a narrow path that went through marshes and forests. The locals said that people went in single-file and waded through mud up to their knees. They took turns carrying the icon, pressing it to their chests." 55

In addition to the renowned Pühtitsa chapel, the Russians of Virumaa have apparently had numerous other village chapels. There are references to former chapels in the contemporary East Viru County, found in the legends collected by Otu Liiv. There were altogether three chapels in the village of Imatu, Illuka rural municipality, Iisaku parish - two to honour Georgi (St. George) and one for Nikolai (St. Nicholas). One of them was demolished in the middle of the 19th century. According to O. Liiv, the old Orthodox chapel of the village of Sompa (Pühtitsa) was still erect in the 1920s. Liiv also noted the abundance of Tsarist era chapels for the Russians in Virumaa and admitted the possibility of there being multiple chapels in one village (see Liiv 1926: 72).

In addition to the chapels and churches in Narva/Ivangorod, there was also an Orthodox church and congregation in Rakvere in 1839 - a two-storied dwelling house was reconstructed as the Church of the Nativity of the Mother of God. The church was thoroughly remodelled and virtually built anew in 18981900 (Berens 1974: 313). 
The first Orthodox church in Mustvee was established in the house of a local resident, $\mathrm{P}$. Boltov, in 1830. The first purpose-built wooden sanctuary was completed with the aid of volunteer donations in 1839 and was sanctified to honour the icon of the Mother of God "Joy to All Sorrowful". This sanctuary was situated in the graveyard and was demolished in $1948 .{ }^{56}$

Some congregations were also formed without building a dedicated church. For example, in Haapsalu, an independent congregation was established in 1836, but the cornerstone of the church was only laid in 1847 and the church was sanctified in 1852. Until the completion of the church, the congregation, which consisted of Russians, gathered in a state-owned building where some rooms on the second floor were adapted for religious use. However, a wooden Orthodox church for the military forces of Haapsalu had already been built in 1756, and was dilapidated by the middle of the 1830s (Berens 1974: 444; EÕK 2007: 52).

Most of the congregations established as a result of the conversion movement in the 1840 s also had to make do with temporary premises at first. Unlike in previous centuries, these congregations mostly consisted of Estonians who had converted from Lutheranism to Orthodoxy. By building new churches for those congregations, a new period of Orthodox sacral buildings began in Estonia.

Congregations established in Estonia and the Estonian parts of Livonia (southern Estonia), before the conversion movement of the 1840s, were affiliated with the Pskovian Bishopric from 1725. Permits to build new churches were issued by the Holy Synod of Russia, founded in 1721. Congregations of northern Estonia were transferred to the jurisdiction of the Metropolitan of St. Petersburg in 1764. Those congregations mainly consisted of Russians. Before the 1840s, Orthodox Estonians were mostly to be found in East Viru County, around lakes Peipsi and Pihkva/Pskov, as well as in the then Oudova County on the eastern (Russian) shore of Lake Peipsi, and in the Setomaa area (see also Klaas 1998: 18-27; Laur 2000: 95-96).

Congregations in the Petseri (Seto) area were part of the Novgorod Archbishopric during the Middle Ages, together with other churches in the Pihkva/Pskov region. In 1589, an independent Bishopric of Pskov and Izborsk was founded, in the course of establishing the Patriarchate of Moscow. The Bishopric of Pskov continued to exist, bearing different names, under the management of the Pskov Consistory until 1919.57

Of the churches that were built in the 18th century until the middle of the 19 th century and which are in the territory that is currently part of Russia and have been preserved, the church of St. Sergi (Sergius) in Irboska (Izborsk in Russian) was constructed probably during the 1750s, the Church of the Holy Great Martyr Varvara (Barbara) in Petseri (Pechory) was completed in 1779, 


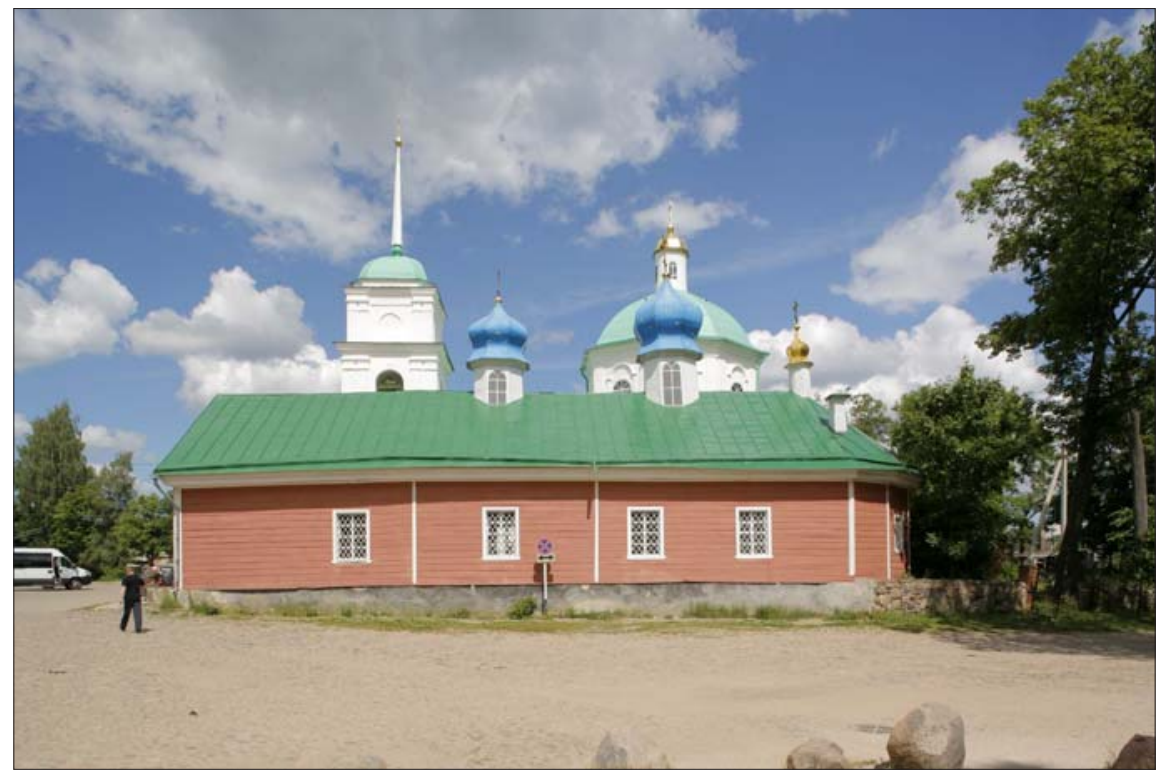

Photo 10. The Church of the Holy Great Martyr Varvara (Barbara) in Petseri/Pechory (completed in 1779). Photo by Arne Maasik 2008.

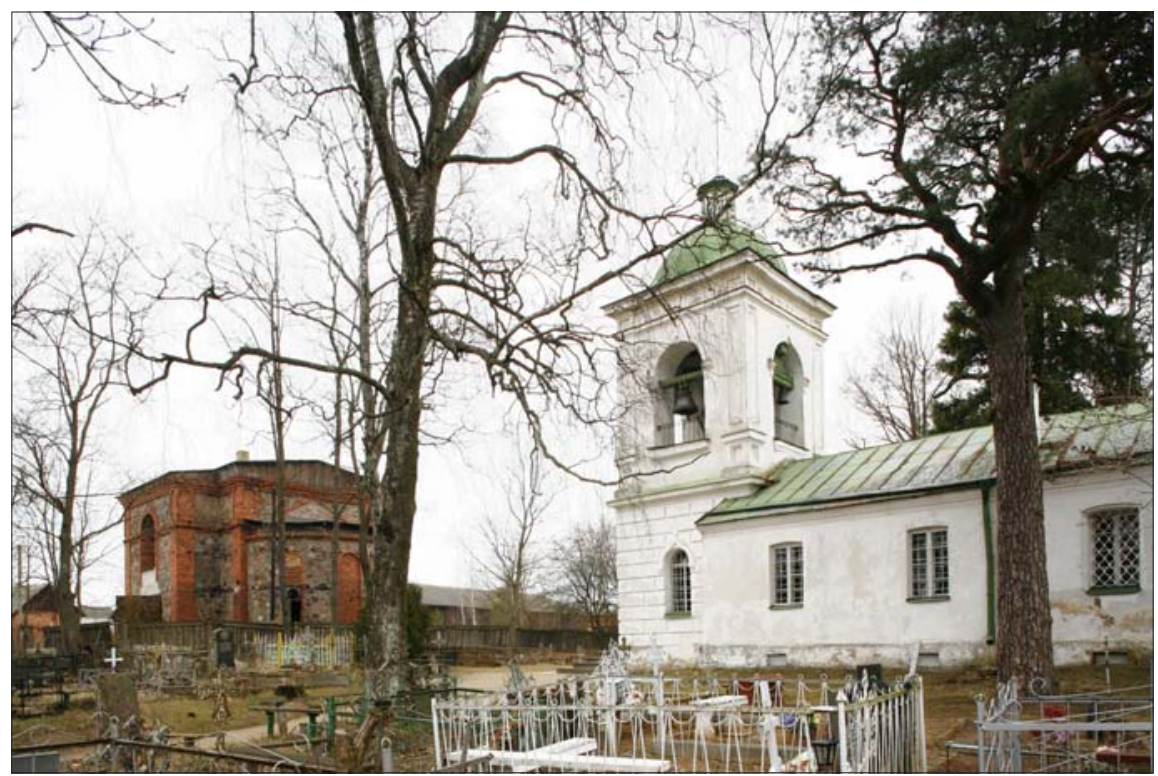

Photo 11. The Church of St. Paraskeva the Great Martyr in Saatse (consecrated in 1801). Photo by Arne Maasik 2008. 
the Trinity Church in Saalesja (Zalesye) was built during the 1790s, and the Church of the 40 Holy Martyrs in Petseri was completed in 1817 . These churches were built of stone, except the church of Varvara, which is the oldest of the preserved wooden churches of the Petseri area, and is now the only church in the Russian part of Setomaa where, in addition to the Russian language, services in the Seto dialect of Estonian were held on a regular basis even at the beginning of the 21 st century. ${ }^{58}$

Of the Orthodox churches in the Estonian part of Setomaa, the stone church of St. Paraskeva the Great Martyr in Saatse was completed in 1801; it is the oldest surviving stone church in the Estonian part of Setomaa, and it still has an active Seto-Russian mixed congregation. ${ }^{59}$

Tsässons in Setomaa were mostly built during the 18th and 19th centuries and there are more tsässons than churches surviving in the Estonian part of Setomaa. In addition to the Mikitamäe and Uusvada tsässons, which were built during the last decade of the 17th century, those in Võõpsu, Rokina and Matsuri (Säpina) have survived; according to the dendro-chronological dating method, they were completed in 1710-1711.

According to dendro-chronology, of the tsässons still existing in the Estonian part, the ones in Meldova (1753), Podmotsa (built approximately in 1760 the oldest date on the tsässon wall) and Serga (1784) were built during the 18th century, and possibly there were some others (see Läänelaid \& Raal \& Valk 2005). In the 19th century, the building of Seto tsässons continued and there have been several built in the 20 th and 21 st centuries. ${ }^{60}$

In addition to these wooden chapels in Setomaa, the prayer houses of the Russian Old Believers on the western shore of Lake Peipsi are also examples of the wooden sacral architecture of 18th-19th century Estonia.

\section{SUMMARY}

Until the conversion movement in southern Estonia, which began in 1845, Orthodoxy in Estonia was mostly the religion of the local Orthodox Russians and Setos, as well as of the Russians living in eastern Estonia, who were officially Lutheran but followed many Orthodox rites (including partially Estonianised Russians, the so-called poluverniks). The Russian Old Believers who settled in Estonia starting at the end of the 17th century can also be counted as Orthodox. The article gives an overview of the spread of Orthodoxy in the current Estonian territory and in Setomaa from the 11th century until 1845, focusing on the establishment of different Russian Orthodox churches and chapels (including the Seto tsässons) in the current territory of Estonia. 
Of the several historical events and Orthodox buildings, which some Estonian church and art historians have so far neglected or underestimated, the following statements or speculations and examples of sacral architecture should be highlighted. Orthodoxy is probably the most ancient form of Christianity to arrive in Estonia, in the 11th century. Some of the local Finno-Ugric people were baptised into Orthodoxy during the 11th-12th centuries, before the crusades of the Roman Catholic Church; it is also possible that the first Christian church in Estonia was founded by the Russian conquerors in Tartu (Yuryev) in the 11th century. The oldest surviving, although extensively reconstructed, Orthodox churches are to be found in Setomaa dating back to the 14th century. The oldest wooden buildings in mainland Estonia also stand in Setomaa: those are the Mikitamäe and Uusvada tsässons (Seto village chapels), built in the last decade of the 17 th century. The Orthodox sacral buildings also include the oldest surviving wooden church in Tallinn - the Kazan Church (1721) and the oldest surviving wooden church in Setomaa - the Church of St. Varvara in Petseri (1779). The latter has been attended by Setos (and Estonians) for centuries, and they have also attended some older churches with Seto-Russian mixed congregations.

From the Setos, the Old Believers and the Russians of present-day eastern Estonia, Orthodoxy might well have spread among Estonians, to some extent. This is attested to by the gatherings near the Pühtitsa chapel and other Orthodox chapels that took place since the 16th-17th centuries and which were attended by Lutheran Estonians as well as Orthodox Russians. Orthodoxy in Estonian towns and eastern Estonia has been promoted by Russian military campaigns and conquests, especially during the Livonian War in 1558-1583 (with the help of the mission of the Petseri (Pechory) Monastery), when dozens of Orthodox churches were erected in Estonia, plus at least one convent in Tartu. Following the Russian defeat in the Livonian War, some Russian-founded Orthodox churches continued to function for some time under the Polish and Swedish reigns.

The notion of the Church of St. Nikolai in Tallinn being the only more or less active Orthodox sacral building in Estonia (excluding Setomaa) by the end of the Swedish period is not accurate, considering the chapels in present-day East Viru County - some of them were also vandalised during that period.

After the Great Northern War, which was won by the Russians, the Lutheran Church maintained its privileges and Orthodox churches were built mostly for Russians until the 1840s. Following Estonia's incorporation into Russia, new Orthodox churches were erected in all the bigger towns and settlements, from Narva to Kuressaare (from east to west) and from Võru to Paldiski (from south to north), as well as in many smaller places in eastern 
Estonia (e.g. Räpina, Nina, Mustvee and Vasknarva), to accommodate the local Russian Orthodox believers and in part as a counterweight to the prayer houses of the Old Believers near Lake Peipsi. With the churches and clerics present in towns, a certain readiness was created for the conversion movement of the Estonians in the 1840s. However, many Estonians had had contacts with Orthodoxy for centuries before the 1840s, particularly in eastern Estonia and in some larger towns.

This article is supported by the Estonian Science Foundation (grant No. 7264).

\section{NOTES}

1 A substantial monograph on the history of Estonian Orthodoxy (since the 11th century) has been written by the previous Patriarch of the Russian Orthodox Church, Aleksius II (Pravoslavie v Estonii 1999, in Estonian 2009). The Orthodox priests Vladimir Berens and August Kaljukosk have made remarkable contributions to the studies of the history of the Estonian Orthodox congregations and churches, but their work has not yet been published (Berens 1974; Kaljukosk 1998). Orthodoxy in Old Livonia has been dealt with in the publications of the historian Anti Selart, who has also written about Medieval Orthodox churches (see Selart 1998a, 1998b, 2006, 2009). Orthodoxy in Setomaa and the Seto tsässons have been dealt by Heiki Valk and many other authors (see Valk 2003; Setumaa 1928; Setomaa 2009).

2 The history of the Old Believers in Estonia has been expanded upon in several publications. See, e.g., Moora 1964; Richter 1976; Pentikäinen \& Raudalainen 1999; Ocherki 2004, 2008; Plaat 2005, 2010; Ponomarjova \& Šor 2006.

3 The first skeet was active in the territory of the Räpina manor in 1710-1722, and the first house of prayer was set up on the western shore of Lake Peipsi in the 1740s, at the village of Kükita (see Richter 1976: 16; Ponomarjova \& Šor 2006: 84-85; Kivistik 2009).

4 The only Edinovertsy congregation in Estonia was established in Mustvee in 1848 (see Plaat 2010: 75-76; Ponomarjova \& Šor 2006: 68-70).

5 Applies to work by Aleksius II, V. Berens, and other Orthodox authors (e.g. Raag 1938; EÕK 2007).

${ }^{6}$ Almost all the currently known Orthodox churches, their ruins, chapels (including the Seto tsässons) and monasteries in Estonia and within the Russian territory of Pechory District (Setomaa) as well as the chapels of Old Believers were photographically recorded. The project and this article were supported by the Estonian Science Foundation (grant No. 7264).

7 See Povest 1849: 3; Drevniaia 1788: 29; Berens 1974: 393; Õigeusu hingekarjased 2002: 11; Phidas 2002: 267; EÕK 2007: 22, 58; Aim 2007: 16; Sild 1931/32: 106, $112-113$.

8 Oral data by the archeologist Ain Mäesalu (2009). 
9 The churches of Nikolai and Georgi are also known as the Church of St. Nikolaos the Miracle Maker, or the St. Nikolaus Church, and the Church of St. Georgios the Great Martyr, or the Church of Georgius or Jüri, respectively.

${ }^{10}$ Data by the archaeologist Heiki Valk (2010).

11 These churches and the few Orthodox people in the town were first mentioned in a Russian travelogue about the journey of the Metropolitan Issidor (Selart 2009: 283; Sõtšov 2004: 14).

12 Several authors among the Orthodox priests claim that these two churches were founded in Yuryev in the 11th century. When Tartu was invaded by crusaders in 1224, the Georgi (St. George's) church was badly damaged. The Grand Duke Svyatoslav had it rebuilt in ten years time, according to the agreement with the municipality (Berens 1974: 393; EÕK 2007: 58; Aim 2007: 18). In general, Estonian historians do not consider these claims to be valid. Some authors even suggest that the Russian merchants in Tallinn might have had their own Orthodox church in the 11th-12th centuries (see Kleinenberg 1962: 242).

${ }^{13}$ According to V. Berens, the wooden Nikolai (St. Nicholas') Church had been restored (after the fire in 1433) by 1437 at the latest, at a new location, near the present Nikolai Church in Vene street (Berens 1974: 363).

14 The new iconostasis of the Nikolai Church was made in 1685-1686 and part of it has survived up to today, some other icons were added later (see Ikonnikov 1889: 20-67; Berens 1974: 363-365; Tallinna 2009: 43; Pantelejev et al. 2002: 13-15, 28-30; Kormashov 2005: 430; http://www.orthodox.ee/indexest.php?d=ajalugu/usk (henceforth: Õigeusk Eestimaal).

${ }^{15}$ According to V. Berens, the new Nikolai Church was mentioned for the first time in 1341, when the altar was consecrated (1974: 76-77). According to Nikolai Raag, the limestone church was completed in 1349 (1938: 26). The Church of St. Nikolai (St. Nicholas) in Irboska belonged to the monastery, which was abolished in 1764 by a decree issued by Catherine II of Russia. After that, the church was converted into a congregational church (Setomaa 2009: 329). By 1934, the mixed congregation of the church included 341 Estonians-Setos and 5,297 Russians (Raag 1938: 32).

${ }^{16}$ By 1934, the Kulkna congregation included 444 Estonians-Setos and 988 Russians, the Mõla congregation included, accordingly, 1,055 and 922, and the Tailova mixed congregation included 1,733 Estonians-Setos and 1,158 Russians (Raag 1938: 32$33)$.

${ }^{17}$ Thus, the Church of St Nikolai (St. Nicholas) in Irboska has been repeatedly rebuilt and renovated over the centuries (Setomaa 2009: 240, 258; Raag 1938: 26). The Kulkna (Kolpino) Church of the Transfiguration of Our Lord on Kolpino Island located in Lake Pskov is probably the second oldest of the preserved Russian-Seto mixed congregation churches, and it has been rebuilt four times in the 19th century alone $(1847,1857,1874,1897)$. The Kulkna Church is quite possibly the same church as the Church of the Nativity, established in the 16th century by Kornelius, Igumen of the Pskovo-Pechersky Monastery on Kolpino Island. The inscription on the church bell indicates that the church on the island dates back to 1558 (Raag 1938: 27). Several other churches in Pechory have been rebuilt many times, especially until the beginning of the 20th century, altering their appearance to a great degree. 
${ }^{18}$ Later, the monastery was re-established, but closed by the reforms made by Catherine II of Russia in 1764, when the Mõla congregation was founded (Setomaa 2009: 214, $240,329)$. The beginning of the 21 st century saw the renovation of the bell tower, dating back to the 16th century (Tihhon 2007: 597).

19 The current stone Church of St. George (Jüri) in Värska, which was completed in 1907, was built on the same site that the wooden church, established in 1877 (Raag 1938: 30-31).

${ }^{20}$ Traces of ancient beliefs and world-views can be found in the Seto traditions and beliefs to this day, although their heyday stayed well in the period before the beginning of the 20th century (Setomaa 2009: 334).

${ }^{21}$ Most often, the Seto tsässons are named after a saint. Rarer are the cases when a tsässon has been named after a church holiday: for example, the tsässons in Mikitamäe.

${ }^{22}$ By way of exception, the village holiday of Uusvada is not celebrated on a tsässon holiday but on St. Peter's Day (Piitrepäiv in the Seto language), i.e. the commemoration day of Apostles Peter and Paul. Hence, the tsässon is sometimes also called St. Peter's Day tsässon that is obviously not correct.

${ }^{23}$ According to several Orthodox authors, Kornelius founded the Trinity Church near Aheru Lake (in present-day Valga County) at a place called Agavere (Kase 1999; EÕK 2007: 58-60; Tihhon 2007: 20), which no longer appears on maps. The founding of Ahero church by Kornelius in Valgamaa, on the shore of Suure-Ahero Lake, was confirmed in the publication Setumaa in 1928, which claims the location of the church (which had probably been destroyed after the Livonian War) had been forested until 1860. When the trees were uprooted, walls and stone tiles, fragments of a chandelier and a Greek-Catholic cross were found. But the objects have been lost through the years (Setumaa 1928: 356-357).

${ }^{24}$ Icons and church implements were taken along by the retreating Russian troops also from other Orthodox churches built during the Livonian War. Part of the treasure reached the Pechersky Monastery (Selart 1998b: 24).

${ }^{25}$ The first bishop was a namesake of the Pechersky Igumen Kornelius. He was followed by at least two more bishops, probably before 1582 (Selart 2006: 16).

${ }^{26}$ A monastery known by its name is the Monastery of the Resurrection of Christ in Tartu. Its buildings, probably built of wood, were possibly constructed after establishing the monastery between the years 1558 and 1570. Services were held immediately after the invasion in "our own church", which was probably the medieval church of Nikolai (St. Nicholas), which was once used and is now being used again. The building of a new church was initiated at once. It was probably not the only one, as Russian churches were built on the northern bank of the River Emajõgi, where a new Russian suburb emerged. The Church of the Transformation of the Lord is also known by its name. It was probably a wooden church that was taken down for building materials or heating wood when Tartu was under the Polish reign after the Russian troops and most of the Russian inhabitants had left. In the 1580s, the Russian chapel built during the Livonian War in the mercantile premises on the opposite bank of the river was still there (see Selart 2006: 10-15, 18, 20-21). 
${ }^{27}$ A revision made by the Polish authorities lists among the churches of the town: "a small wooden church of Moscovites where nowadays Catholic services are held ... Russian church next to the parish church of Jaani (St. John's) in the marketplace, where Lutheran Germans gather for their service." (Viljandi 1999: 14)

${ }^{28}$ After the Swedes had conquered the Ivangorod stronghold in the Livonian War (1581), the church was transformed into a Lutheran church. It was reclaimed by the Orthodox congregation during the 1740s (Ivask \& Sinjakova 2005: 9-10,25). The churches of Ivangorod, which have mostly been part of the Russian state, will not be discussed further in this article (for information regarding them, see Ivask \& Sinjakova 2005).

${ }^{29} \mathrm{http}: / /$ www.orthodox.ee/indexest.php?d=kuremae/kloos.

${ }^{30}$ Annual gatherings around the Pühtitsa chapel have been reported since the second half of the 17th century. There was supposedly a great gathering of people in Kuremäe every year, against which the efforts and threats made by the local Lutheran pastors and the prohibitions of the province government were powerless. In 1699, the Jõhvi pastor reported that people came to the great heretical party, held in August, from several parishes and even from Russia (Liiv 1928: 81-92).

${ }^{31}$ In the 1738 visitation of the church in Jõhvi, one Russian chapel was mentioned, among others, which was supposedly erected without the permission of the Governor General and where an Orthodox priest and a lot of Russians gathered once a year, together with many (Estonian) Lutherans. The latter were prohibited from attending in the future (Liiv 1928: 81-82). The chapel in question was probably that of Kuremäe, which was supposedly held sacred by the local Estonian peasantry even before the revelations in the 16th century, after which it became sacred for the local Russians as well.

${ }^{32}$ Russian peasants in Vasknarva had built a new wooden chapel next to the small wooden one by 1876 . In 1885, it became the church for the local congregation (Pjuhtitskii 1991: 3-4).

${ }^{33}$ For details about Russians, in East Viru County, who were officially Lutheran, but in practice followed the Orthodox (and pagan) rites, see Liiv 1928: 68ff.

${ }^{34}$ According to the estimates of Jüri Truusmann, the Russians who were the forefathers of poluverniks wandered there from Russia during the 16th and 17th centuries (2002: 179). According to Ott Kurs, the Orthodox Russians appeared there even earlier, from the 13th to 16th centuries (2006: 102).

${ }^{35}$ In the author's opinion, the massive conversion of Lutherans to Orthodoxy that took place in the 1840 s actually denoted their transfer to another church, not a change of religion. Most of the converts did not know much about Orthodoxy and many continued to attend Lutheran churches or Hernhutian congregations and followed the Lutheran rites. The principles of Orthodoxy started to take hold only during the following decades.

${ }^{36}$ This church, which was built during the 17th century and had been closed for a while, was given to the German congregation in 1733. It was wrecked during the bombing in 1944, and the ruins were finally demolished during the 1950s (Ivask \& Sinjakova 2005: 11, 13, 18). 
${ }^{37}$ The oldest known stone church of Narva was first mentioned in 1442 . The church, which had been active as a Catholic and also Lutheran church, as well as an Orthodox one, from 1708 to 1944, was badly damaged in the 1944 bombing and its ruins were finally removed in the 1950s (Ivask \& Sinjakova 2005: 11, 26; EÕK 2007: 82).

${ }^{38}$ The Nikolai (St. Nicholas') Church of Tallinn in Vene street was the hospital for the Swedish military forces during the Great Northern War, but was reopened as the church after the Russian conquest in 1710 (Ikonnikov 1889: 20-67).

${ }^{39}$ The iconostasis of the church was completed, but its erection began only in 1726 , after the old church had been renovated and reconstructed. It was finished only in 1732 (Kaljundi 2005: 439). See Tiisik 1896 for details of the church.

${ }^{40}$ According to another version, the church was finished in 1721 and brought to its present location in 1749 (Tallinna 2009: 71).

${ }^{41}$ Tallinna 2009: 75-76; Berens 1974: 371, see also www.eoc.ee/est/esileht/piiskopkonnad, (bishoprics of the Estonian Apostolic Orthodox Church).

${ }^{42}$ See Aleksius II 1999: 144-145. There were two churches with congregations, and four military churches in Tallinn by 1799 (Berens 1974: 352).

${ }^{43}$ According to other records, this church, which is situated in Magasini Street, was designed by the Rigan architect A. Pavlos. Side wings were added in the 1840s (architect A. Adamson), and there were other reconstructions and annexes added later (Eesti Arhitektuur 4... 1999: 37; Raid 1981: 52-53).

${ }^{44}$ In 1888, the Swedes from the isles of Suur-Pakri and Väike-Pakri joined the Paldiski congregation, as well as Estonians who had converted to Orthodoxy in the 1880s. According to V. Berens, they held services in Swedish and Estonian, and in 1886, an Orthodox auxiliary school was established in Suur-Pakri (1974: 268-269). The connection of Estonian Swedes (incl. the Swedes from the island of Vormsi - see Plaat 1999 for details) with the Orthodox church is one of the most interesting chapters in the history of Estonian Orthodoxy, as well as one of the most peculiar ones.

45 About Orthodoxy in Saaremaa, see Plaat 2003.

46 Berens 1974: 165-166; Toon 1997: 4-6; Aleksius II 1999: 148-149. The Russian community was small in number until the middle of the 19th century. It is also worth mentioning that, by the 19th century at the latest, some Dukhobors and other Russian Orthodox denominations were located in Saaremaa: these were deported from Russia by the authorities (Aleksius II 1999: 601).

47 About the churches in Narva and Ivangorod, see Berens 1974: 229-248; Ivask \& Sinjakova 2005; EÕK 2007: 82-91.

${ }^{48}$ According to other records, the Võru church, with its Neo-classicist silhouette and details, was completed in 1806 (Eesti Arhitektuur 4... 1999: 147; Võrumaa 1926: 461).

${ }^{49}$ Mustvee was declared a town in 1938, and Räpina in 1993.

${ }^{50}$ In the 20th century, the church was expanded by adding an annex for side altars (Berens 1974: 255-256; EÕK 2007: 76-78). 
${ }^{51}$ In the period of $1752-1844$, the Räpina congregation had about 400 to 600 Russian members. However, after the movement to convert Estonians, which started in 1845, the congregation had 2,057 members in 1847 (Hindo 1937: 22-24; Berens 1974: 323-327; Aleksius II 1999: 149; Tohvri 2004: 56).

${ }^{52}$ Berens 1974: 82; EÕK 2007: 68. The new stone church in Vasknarva was completed in 1873.

${ }^{53} \mathrm{http} / / /$ www.orthodox.ee/indexest.php?d=kuremae/kloos. After the Kuremäe Church of the Dormition of the Mother of God was established in Pühtitsa in 1891, the miraculous icon was transferred there.

${ }^{54}$ The tradition of a procession from Vasknarva to Pühtitsa on the Day of the Dormition of the Mother of God (Aug 28) is still followed (Interview with Mother Prokopi, in Vasknarva, 09/14/2009).

${ }^{55} \mathrm{http} / / /$ www.orthodox.ee/indexest.php?d=kuremae/kloos.

${ }^{56}$ The current stone church of St. Nikolai the Holy Bishop and Miracle Worker was built in Mustvee during 1861-1864, designed by A. Edelson, the architect to the Rigan Bishopric (Berens 1974: 205; EÕK 2007: 74).

${ }^{57}$ On 17 June 1919, the council of the Bishopric of Estonia assigned a provost to Petseri County, giving him orders to organise a deanery from the 16 existing Orthodox congregations (Setomaa 2009: 326-327).

${ }^{58}$ As of 2008, Russian-only services have been held in the mixed congregations of Tailova, Zalesye, Pankjavitsa and Mõla. The church of Laura was mostly attended by Russians and Latvians. The other Orthodox Estonian Setos living in Petseri (in Vana-Irboska and elsewhere) attended purely Russian congregations. (Interview with Yevgeni Peleshev, the priest of the Varvara congregation of Petseri, 30 June 2008, in Petseri).

59 About the churches in Setomaa, see Raag 1938; Berens 1974; Setomaa 2009.

${ }^{60}$ There are 23 tsässons and 6 Orthodox churches located within the Estonian territory of Setomaa in 2011.

\section{REFERENCES}

Aim, Aleksandr 2007. Istoriia Tartuskogo Sviato-Georgievskogo pravoslavnogo prikhoda. Tartu: A. Aim.

Aleksius II 1999 = Patriarkh Aleksii II. Pravoslavie v Estonii. Moskva: Pravoslavnaia entsiklopediia, Moskovskie uchebniki.

Aleksius II 2009. Öigeusk Eestimaal. Tallinn: Moskva Patriarhaadi Kirjastus, Kirjastus Revelex.

Berens, Vladimir (comp.) 1974. Istoriko-statisticheskoe opisanie tserkvei i prikhodov Severo-Zapadnykh eparkhii. Chast' 2, Estonskaia eparkhiia. Tallinn. (Printed copy of the manuscript kept in the Baltika collection of the Academic Library of Tallinn University). 
Drevniaia 1788 = Drevniaia rossiiskaia vivliofika. Moscow.

EAÕK piiskopkonnad (bishoprics of the Estonian Apostolic Orthodox Church) $=$ official website of the EAÕK (Estonian Apostolic Orthodox Church), www.eoc.ee/ est/esileht/piiskopkonnad, last accessed on 30 March 2011.

Eesti arhitektuur 3... 1997 = Raam, Villem (ed.-in-chief); Tõnisson, Evald et al. (comp.); Masso, Tiit \& Lass, Anne \& Laidre, Sirje (eds.) Eesti arhitektuur 3, Harjumaa. Järvamaa. Raplamaa. Lääne-Virumaa. Ida-Virumaa. [Estonian Architecture 3, Harjumaa. Järvamaa. Raplamaa. Lääne-Virumaa. Ida-Virumaa.] Tallinn: Valgus, 1997

Eesti arhitektuur 4... 1999 = Raam, Villem (ed.-in-chief); Tõnisson, Evald et al. (comp.) Eesti arhitektuur 4, Tartumaa, Jõgevamaa, Valgamaa, Võrumaa, Põlvamaa. [Estonian Architecture 4. Tartumaa, Jõgevamaa, Valgamaa, Võrumaa, Põlvamaa.] Tallinn: Valgus.

EÕK 2007 = Pravoslavnye khramy Estonii = Eesti õigeusu kirikud $=$ The orthodox churches in Estonia. Edited by V. Volohonski. Tallinn: Moskva Patriarhaadi Eesti Õigeusu Kiriku Sinod; Moskva: Vene Õigeusu Kiriku Kirjastusnõukogu.

Hindo, N. 1937. Ap. Õigeusu Räpina kogudus: 1752-1937. [Apostolic Orthodox congregation in Räpina: 1752-1937.] Räpina: Ap. Õig. Räpina kogudus.

Ikonnikov M. T. 1889. Pravoslavnaia tserkov' Sviatitelia i Chudotvortsa Nikolaia Mirlikiiskogo $v$ g. Revele. Revel.

Ivask, Merike \& Galina Sinjakova 2005. Narva religioonielu ajaloost. [About the History of Religious Life in Narva.] Edited by M. Ivask \& V. Jürjo \& T. Mazur \& A. Toode. Narva Muuseumi Toimetised 4. Narva: Narva Museum, pp. 9-41.

Kaljukosk, August 1998. Eesti Apostlik-Õigeusu koguduste ajaloolised andmed. [Historical Data regarding Apostolic-Orthodox Congregations in Estonia.] Tallinn (Manuscript in the EAÕK centre in Tallinn).

Kaljundi, Jevgeni 2005. Issanda Muutmise kiriku ikonostaas. [Iconostasis in the Church of the Transfiguration of Our Lord.] In: K. Kodres (ed.) Eesti kunsti ajalugu 2. 1520-1770. [History of Estonian Art 2. 1520-1770.] Tallinn: Eesti Kunstiakadeemia, pp. 434-439.

Kangropool, Rasmus \& Bruns, Dmitri 1972. Tallinn sajandeis: ehituskunstiline ülevaade. [Tallinn throughout Centuries: Architectural Overview.] Tallinn: Eesti Raamat.

Kase, Olga 1999. Petseri klooster. [Petseri Monastery.] Õigeusk Eestimaal 10 (newspaper of the Cathedral of St. Alexander Nevsky), http://www.infonet.ee/ ettnat/ Petklo.html, last accessed on 30 March 2011.

Kiristaja, Arvis 2005. Saatse ümbruse ajaloost muinasajast tänapäevani. [The History of Saatse Area, from Prehistoric Times up until Today.] In: M. Aun (comp.) \& I. Tammaru (ed.) Saatse muuseum. Tallinn: Setu Kultuuri Fond, pp. 19-44.

Kivistik, Vaike 2009. Vanausuliste pelgupaik Räpinas. [The Refuge of Old Believers in Räpina.] In:V. Kivistik \& V. Tund (compilers) Vene vanausuliste jälgedes Räpinas, Beresjes ja Piirissaarel. [Following the Footsteps of Russian Old Believers in Räpina, Beresje and Piirissaar.] Räpina: Räpina Koduloo- ja Aiandusmuuseum, pp. $3-10$.

Klaas, Urmas 1998. Õigeusu kirik Lõuna-Eestis 1848-1917. Halduskorraldus ja preesterkond. [Orthodox Church in South-Estonia 1848-1917. Administrative Structure and Priesthood.] Master's thesis. Tartu (manuscript is in the Tartu University Library). 
Kleinenberg, Igor 1962. Tallinna vene kaubahoovi ajaloost XV-XVI sajandil. [About the history of the Russian trade-yard in Tallinn, during the XV-XVI centuries.] Eesti NSV TA Toimetised. Ühiskonnateadused 11, pp. 241-257.

Kormashov, Orest 2005. Tallinna Nikolai õigeusu kiriku 17. sajandi ikonostaas. [17thCentury Iconostasis in the St. Nikolai's Orthodox Church in Tallinn.] In: K. Kodres (ed.) Eesti kunsti ajalugu 2. 1520-1770. [History of Estonian Art 2. 1520-1770.] Tallinn: Eesti Kunstiakadeemia, pp. 426-433.

Kurs, Ott 2006. Peipsimaa majandusliku ja kultuurilise siirdevööndina. [Lake Peipsi Area as Economic and Cultural Transition Zone.] In: O. Kurs Rajamaade rahvaid. Tartu: Ilmamaa, pp. 95-109.

Kõpp, Johan 1959. Kirik ja rahvas: sugemeid eesti rahva vaimse palge kujunemise teelt. [Church and People: on the formation of the spiritual worldview of the Estonians.] Stockholm: Eesti Vaimulik Raamat.

Laur, Mati 2000. Eesti ala valitsemine 18. sajandil (1710-1783). [Governance of the Territory of Estonia during the 18th Century (1710-1783).] Scripta Archivi Historici Estoniae. Tartu: Eesti Ajalooarhiiv.

Liiv, Otu [Otto] 1928. Vene asustusest Alutagusel kuni XVIII sajandi esimese veerandini: koos asustuse tulunduselu ja usulise seisundi vaatluskatsega päämiselt Rootsi ajal. [About the Russian Population in Alutaguse, up until the first Quarter of the 18th century.] Tartu: Loodus.

Läänelaid, Alar \& Raal, Ain \& Valk, Heiki 2005. Setomaa tsässonate vanusest: esialgseid andmeid. In: I. Puura \& S. Pihu (eds.) XXVIII Eesti looduseuurijate päev. Setomaa loodus. 2.-3. juuli, 2005. [XXVIII Estonian Naturalists' Congress. Nature in Setomaa. 2-3 July, 2005.] Obinitsa. Tartu: Eesti Looduseuurijate Selts, pp. 37-46.

Moora, Aliise 1964. Peipsimaa etnilisest ajaloost: ajaloolis-etnograafiline uurimus EestiVene suhetest. [Ethnic History of Peipsi Area: historical-ethnographic study about Estonian-Russian relationships.] Tallinn: Eesti Riiklik Kirjastus.

Muistendid 1963 = Laugaste, Eduard (comp.) et al. Muistendid Suurest Tóllust ja teistest: Hiiu- ja vägilasmuistendid. [Legends of Suur Tõll and others: hero-legends and legends from Hiiumaa.] Tallinn: Eesti Riiklik Kirjastus.

Ocherki 2004 = Külmoja, Irina (ed.) Ocherki po istorii $i$ kul'ture staroverov Estonii I. [About the History and Culture of Old Believers I.] Tartu: Izdatel'stvo Tartuskogo universiteta.

Otsherki 2008 = Külmoja, Irina (ed.) Ocherki po istorii i kul'ture staroverov Estonii II. [About the History and Culture of Old Believers II.] Tartu: Izdatel'stvo Tartuskogo universiteta.

Pantelejev et al. 2002. = Panteleev, Aleksandr \& Nikolai i Orest Kormashovy. Nikol'skaia tserkov'v Tallinne $=$ Nikolai kirik Tallinnas $=$ St. Nicholas' Church in Tallinn . Tallinn: Avenarius.

Pentikäinen, Juha \& Raudalainen, Taisto 1999. Old Belief among the Uralic Peoples. The Priestless Pomortsy in the Baltic area. In: J. Pentikäinen (ed.) Silent as Waters We Live: Old Believers in Russia and Abroad: Cultural Encounter with the Finno-Ugrians. Helsinki: Finnish Literature Society, 1999, pp. 84-96.

Phidas, Vlasios 2002. The Church of Estonia. The autonomous orthodox church of Estonia $=$ L'Église autonome orthodoxe d'Estonie (approche historique et nomocano- 
nique). Sous la direction de Archim. Grigorios D. Papathomas et R. P. Matthias H. Palli. Athènes: Éditions Épektasis, pp. 267-273.

Pjuhtitskii 1991 = Piukhtitskii Uspenskii zhenskii monastyr': 100 let (1891-1991 gg).

Plaat, Jaanus 1999. Vormsi usk: usuliikumised Vormsi rootslaste ja eestlaste seas 1740.-1990. aastail. [Religion in Vormsi: religious movements among the Swedes and Estonian on Vormsi Island.] Akadeemia, Vol. 2, pp. 277-309.

Plaat, Jaanus 2003. Saaremaa kirikud, usuliikumised ja prohvetid 18.-20. sajandil. [Churches, Religious Movements and Prophets in Saaremaa during the 18th 20th Centuries.] Tartu: Eesti Rahva Muuseum.

Plaat, Jaanus 2005. The Identity and Demographic Situation of Russian Old Believers in Estonia. (With Regard to the Period of the 18th to the Early 21st Century). Pro Ethnologia 19, pp. 7-31.

Plaat, Jaanus 2010. Russian Old Believers and Edinovertsy in Estonia and their monasteries, churches and houses of worship. Regional Review / Regionalais Zinojums, Vol. 6, pp. 73-84.

Ponomarjova, Galina \& Šor, Tatjana 2006. Eesti vanausulised: väike kirikuloo teatmik = Староверы Эстонии: краткий исторический справочник = The old believers of Estonia: a brief historical survey. Compiled by P. Varunin Tartu: Eesti Vanausuliste Kultuuri- ja Arendusühing.

Povest 1849 = Povest' o nachale $i$ osnovanii Pskovo-Pecherskogo pervoklassnogo monastyria, vziataia iz drevnikh letopistsev, obretaiushchikhsia v knigokhranitel'nitse etogo monastyria. 2-e izd. Pskov.

Pärnumaa 2001 = Tamm, Egle \& Viilma, Urmas (comp.) Pärnumaa kirikud. [Churches in Pärnumaa.] Pärnu: Pärnu Maavalitsus.

Raag, Nikolai 1938. Petserimaa kogudused. [Congregations in Petserimaa.] Usuteadusline Ajakiri 1, pp. 24-35.

Raid, Niina 1981. Tartu vanemaid ehitisi. [Oldest Buildings in Tartu.] Tallinn: Eesti Raamat

Richter, Jelizaveta (=Rikhter, Elizaveta ) 1976. Russkoe naselenie zapadnogo Prichud'ia (ocherki istorii, material'noi i dukhovnoi kul'tury). Tallin: Valgus.

Russow, Balthasar 1993. Liivimaa kroonika. [The Chronicle of Livonia.] Tallinn: Hotger.

Selart, Anti 1998a. Eesti idapiir keskajal. [Estonia's eastern border during the Middle ages. Tartu: Tartu Ülikooli Kirjastus.

Selart, Anti 1998b. Petseri klooster ja Liivi sõda. [Petseri Monastery and the Livonian War.] Ajalooline Ajakiri, Vol. 2, pp. 19-28.

Selart, Anti 2006. Õigeusu klooster Liivi sõja aegses Tartus. In: T. Tannberg (comp.) Vene aeg Eestis. Uurimusi 16. sajandi keskpaigast kuni 20. sajandi alguseni. [Russian Rule in Estonia. Research from the middle of the 16th century up until the beginning of the 20th century.] Eesti Ajalooarhiivi toimetised 14 (21). Tartu: Eesti Ajalooarhiiv, pp. 9-23.

Selart, Anti 2009. Orthodox churches in medieval Livonia. In: A. V. Murray The Clash of Cultures on the Medieval Baltic Frontier. Farnham, Burlington: Ashgate, pp. 273-290.

Setomaa 2009 = Valk, Heiki \& Selart, Anti \& Lillak, Anti (comp. \& eds.) \& Aun, Mare (ed.-in-chief). Setomaa 2. Vanem ajalugu muinasajast kuni 1920. aastani. [Setomaa 2. Older history from the prehistoric times until 1920.] Tartu: Eesti Rahva Muuseum. 
Setumaa 1928 = Tammekann, August Ferdinand \& Kant, Edgar \& Veski, Johannes Voldemar (eds.) Setumaa: maadeteaduslik, tulunduslik ja ajalooline kirjeldus. [Setumaa: geographical, economic and historical description.] Tartu: Eesti Kirjanduse Selts.

Sild, Olaf 1931/32. Kas hommiku poolt tuli ristiusulisi mõjusid paganausulistele eestlastele. [Were Pagan Estonians Affected by Christian Implications from the East.] Usuteadusline Ajakiri 3/4, pp. 101-116.

Sõtšov, Andrei 2004. Eesti õigeusu piiskopkond Stalini ajal aastail 1945-1953. [Estonian Orthodox Bishopric during the Stalinist Era 1945-1953.] Tartu: Tartu Ülikooli Kirjastus.

Tallinna 2009 = Liivik, Olev \& Dubovik, Boris (comp.) Tallinna kirikud. Ajalugu ja restaureerimine. [Tallinn Churches. History and Restoration.] Texts written by E. Tamm \& O. Liivik. Tallinn: Tallinna Kultuuriväärtuste Amet.

Tamm, Egle 2001. Moodsad kirikud: Eesti 1920.-1930. aastate sakraalarhitektuur. [Modern Churches: the Architecture of Sacral Buildings in Estonia during the 1920s-1930s.] Tallinn: Eesti Arhitektuurimuuseum

Tarvel, Enn 1987. Henrik ja tema aeg. In: J. Kivimäe (comp.) Religiooni ja ateismi ajaloost Eestis 3. [The History of Religion and Atheism in Estonia 3.] Tallinn: Eesti Raamat, pp. 7-32.

Tiisik, Karp (=Tizik, Karp) 1896. Istoriia Revel'skago Preobrazhenskago Sobora: istoriko-statisticheskoe opisanie. Revel: G. Matizen

Tihhon (=Arkhimandrit Tikhon (Sekretarev)) 2007. Vrata nebesnye; Istoriia SviatoUspenskogo Pskovo-Pecherskogo monastyria. Pechory: Sviato-Uspenskii PskovoPecherskii monastyr'.

Tohvri, Epi 2004. Ehitusmeistrist arhitektiks - G. F. W. Geist Tartu linnaruumi kujundajana 19. sajandi esimesel poolel. [From master builder to architect - G. F. W. Geist as designer of Tartu urban space in the first half of the 19th century.] Kunstiteaduslikke uurimusi/Studies on Art and Architecture, Vol. 3-4, pp. 50-77.

Toon, Martin 1997. EAÕK Kuressaare Püha Nikolai Koguduse ajalugu. [The History of the Estonian Apostolic Orthodox Church of Nikolai (St. Nicholas) in Kuressaare.] Kuressaare: EAÕK Kuressaare Püha Nikolai Kogudus.

Truusmann, Jüri 2002. Petserimaa setud. Mäetagused, Vol. 19, pp. 176-190.

Tvauri, Andres 2001. Muinas-Tartu: uurimus Tartu muinaslinnuse ja asula asustusloost = Prehistoric Tartu: $a$ study of the settlement history of the Tartu prehistoric hillfort and settlement. Tartu \& Tallinn: Teaduste Akadeemia Kirjastus

Valk, Heiki 2003. Tsässon ja külakalmistu Põhja-Setomaa kultuuripildis. [Tsässon and village cemetery in the cultural landscape of Northern Setomaa.] In: M Aun (comp.) \& Ü. Tamla (ed.) Setumaa kogumik 1. Uurimusi Setumaa arheoloogiast, numismaatikast, etnoloogiast ja ajaloost. [Setumaa Collection 1. Research on the archaeology, numismatics, ethnology and history of Setumaa.] Tallinn: Ajaloo Instituut, pp. 219-252.

Viljandi 1999 = Viljandi linn 1599. aastal. [Viljandi town in 1599.] Viljandi Muuseumi Aastaraamat 1998. Viljandi: Viljandi Muuseum, pp. 114-162. http:// www.muuseum.viljandimaa.ee/?op=body\&id=111, last accessed on 20 March 2011. 
Võrumaa 1926 = Võrumaa: maadeteaduslik, tulunduslik ja ajalooline kirjeldus. [Võrumaa: geographical, economic and historical description.] Edited by J. Rumma \& A. Tammekann \& J. V. Veski. Tartu: Eesti Kirjanduse Selts.

Õigeusk Eestimaal $=$ Moskva Patriarhaadi Eesti Õigeusu Kiriku ajalugu. Õigeusk Eestimaal - http://www.orthodox.ee/indexest.php?d=ajalugu/usk, last accessed on 30 March 2011.

Õigeusu hingekarjased 2002 = Schutting, Riina (transl.); Hirvoja, Toomas \& Pau, Merike (eds.) Öigeusu hingekarjased Eestimaal. [Orthodox priests in Estonia.] Tallinn: Püha Issidori Õigeusu Kirjastusselts. 